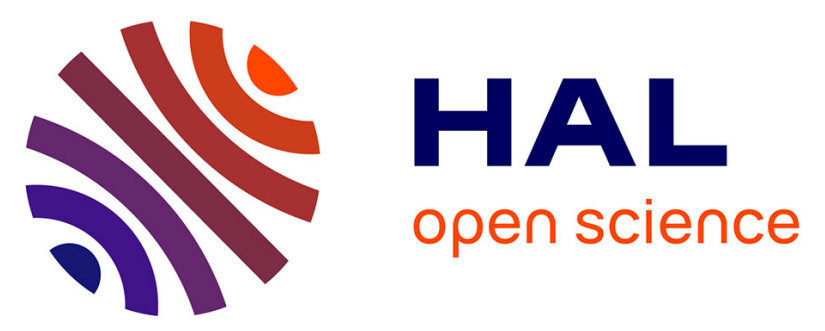

\title{
A new understanding of the chronology, circulation and function of Iron Age (8th-1st c. BC) ferrous semi-products in north-eastern France
}

Marion Berranger, Philippe Dillmann, Philippe Fluzin, Enrique Vega, Michel Aubert, Stéphanie Leroy, Emmanuelle Delqué-Količ

\section{To cite this version:}

Marion Berranger, Philippe Dillmann, Philippe Fluzin, Enrique Vega, Michel Aubert, et al.. A new understanding of the chronology, circulation and function of Iron Age (8th-1st c. BC) ferrous semiproducts in north-eastern France. Archaeological and Anthropological Sciences, 2021, 13 (6), pp.102. 10.1007/s12520-021-01333-0 . cea-03244046

\section{HAL Id: cea-03244046 https://hal-cea.archives-ouvertes.fr/cea-03244046}

Submitted on 22 Dec 2021

HAL is a multi-disciplinary open access archive for the deposit and dissemination of scientific research documents, whether they are published or not. The documents may come from teaching and research institutions in France or abroad, or from public or private research centers.
L'archive ouverte pluridisciplinaire HAL, est destinée au dépôt et à la diffusion de documents scientifiques de niveau recherche, publiés ou non, émanant des établissements d'enseignement et de recherche français ou étrangers, des laboratoires publics ou privés. 


\title{
A new understanding of the chronology, circulation and function of Iron Age (8th-1st c. BC) ferrous semi-products in north-eastern France
}

\author{
Marion Berranger, Philippe Dillmann, Philippe Fluzin, Enrique Vega, Michel Aubert, \\ Stéphanie Leroy, Emmanuelle Delqué-Količ
}

\begin{abstract}
In Europe, several thousand ferrous semi-products attributed to the Iron Age (8th-1st c. BC) have been found. Recent advances in the field of archaeometry concerning the dating of iron objects, characterisation of materials and provenance studies have made it possible to address some important and hitherto unresolved questions. The results obtained from the study of an exceptional set of over 70 currency-bars found in north-eastern France shed new light on their chrono-cultural context, which is much older than previously thought. This interdisciplinary approach also made it possible to propose a new interpretation of the production, circulation and deposition conditions of these semi-products.
\end{abstract}

\section{Introduction}

During the earliest period of iron metallurgy in Western Europe, iron was traded as semi-products. The different mor- phologies of these semi-products varied from pieces of raw metal to bipyramidal and quadrangular bars, hooked billets and flat bars with one rolled-up extremity. Several thousand examples attributed to the Iron Age (8th-1st c. BC) have been discovered over the years. Specimens presenting similar mor- phologies, with regional variations, have been recovered over a large geographical area, from Great Britain to Germany, and further east to Poland, indicating a certain degree of standardisation.

In the majority of cases, these iron semi-products have been discovered in poorly established contexts, where chronologi- cal data are scarce. Consequently, it is usually impossible to propose a precise typochronology for these kinds of products. However, recent advances in the field of archaeometric studies now make it possible to address some key, previously unan- swered questions. For example, radiocarbon dating of the car- bon entrapped in the metallic matrix of these metal masses permits a revaluation of their production periods. This method was first applied to bipyramidal bars (Bauvais et al. 2017) attributing them to the first Iron Age (between 800 and 400 cal. BC) and not to Antiquity, as had been proposed based on a misinterpretation of the archaeological contexts (Kleeman 1981). The present article focusses on another type of semi- product, in the form of flat bars with one rolled-up extremity, called "currency-bars". According to the archaeological con- texts, these semi-products seem to have emerged over the course of the $3 \mathrm{rd}$ c. BC, becoming numerous during the $2 \mathrm{nd}$ and $1 \mathrm{st} \mathrm{c}$. BC. The results obtained here using radiocarbon dating shed new light on the chrono-cultural context of the semiproducts, which seems to be much older than originally assumed. Additionally, an initial typochronology for currency-bars is proposed.

Produced during a period when iron metallurgy was rapidly developing, both qualitatively and quantitatively, most of the currency-bars discovered are specimens that had been re- moved from the trade network. Most were found in artefact deposits isolated from other associated material or evidence of human occupation, raising questions about their status, and even their function. The name currency-bar dates back to the early twentieth century and is a reference to the phrase by Julius Caesar in Commentarii de Bello Gallico ("Untuntur aut aere, aut nummo aureo, aut taleis ferreis ad certum pondus examinatis pro nummo" - César Book V, Chapter 12) which mentions, in addition to gold coins and brass, the existence 
of iron bars of a certain determined weight used as currency in Britannia. Previous studies have focussed on comparisons of their morphology and metrological charac- teristics in order to determine the degree of standardisation. This is sometimes attributed to their function as premonetary items (Allen 1967) or, to the contrary, is considered a conse- quence of their standardised production conditions (Crew 1994).

In either case, as metal stocks, these objects provide infor- mation about the circulation of goods and the organisation of trade networks. In this article, a metallographical approach was employed to study the manufacturing techniques and the nature of the materials used, with the objective of reconstructing the production and trade conditions. The paper also seeks to determine the quality of the materials in circulation and the expertise used in the metalworking processes. In addition, chemical provenance markers of the slag inclusions entrapped in the metallic matrices were analysed. The results make it possible to follow the trajectory of the metal masses constituting these semi-products, from their sites of produc- tion and shaping to their place of deposit, and to recreate the transformation techniques used before their abandonment. The findings also attest to the number of actors involved in the fabrication of these objects and their level of specialisa- tion. Finally, the study of their chrono-cultural context, fabri- cation and their deposit conditions make it possible to revisit the context of their exclusion from the trade network.

These questions have been addressed through the interdis- ciplinary study of an exceptional set of 73 currency-bars found in central-eastern France. The large quantity of objects and their consistency permits a comparative approach to their pro- duction, circulation and deposit conditions, which had been generally proven difficult to address due to the poor quality of the documentation.

\section{Corpus and methods}

\section{Corpus and discovery context}

A total of 73 bars from ten locations were examined. These discovery sites belong to three distinct places of origin (Fig. 1b) that constitute the heart of a larger concentration extending as far as Switzerland and south-western Germany (Fig. 1a).

Some 31 currency-bars were recovered from the bed of the Saône River near Chalon-sur-Saône, in the Saône-et-Loire and Côte-d'Or departments in France (Berranger and Fluzin 2016). They were discovered during dredging operations car- ried out in the 1970s and 1980s. These specimens were col- lected at four different sites: four at the Gué des Piles in Chalon-sur-Saône, one in Pouilly-sur-Saône, 14 at the Île au Bœuf in Seurre and 12 at Port Guillot in Saint-Marcel. In several cases, these objects were found in groups of two, three or five, in arrangements indicating that they had fallen into the river simultaneously, in perishable containers. The excava- tions and dredging operations carried out along the course of the Saône highlighted the extraordinary wealth of the river, which yielded quantities of objects abandoned near fords over very long periods (Dumont 2002, p. 193). This set of speci- mens will be referred to as the "Saône River group".

The deposit in Champdivers (Jura department) was located on the banks of meanders of the Doubs River. During the Hallstatt and early La Tène periods, the Doubs appears to have been unsuitable for navigation, whereas in the late Iron Age, the river seems to have been a single, navigable and navigated channel, according to Strabo and the discovery of Dressel 1b amphorae along its course (Daubigney et al. 2007). Several series of objects were collected in the 1980s and 1990s at Le Grand-Glairon during quarry operations covering approxi- mately $1 \mathrm{~km}^{2}$ right on the banks of the Doubs. Seven currency-bars were found alongside iron objects dating be- tween the La Tène A and the early Middle Ages (ibid.). This set will be referred to as the "Doubs-Champdivers group".

The region of Salins-les-Bains (Jura department) corre- sponds to a privileged zone of passage between the plains of the Saône and the Swiss plateaus, where the exploitation of salt water springs from the Neolithic period onwards notably contributed to economic development and increasing trade (Pétrequin et al. 2001). Five deposits were unearthed in rocky areas, most at a depth of only a few centimetres. A total of 35 semi-products were found including 26 currency-bars from Le Dafoy-Mont Poupet in SaintThiébaud, four from the Bois de Rafour in Valempoulières and two from near the Pré des Noyers in Arbois. At Salins-les-Bains, Bois Bovard-les Rappes and Bois Bovard-est, two deposits were discovered in rocky 
cracks about $500 \mathrm{~m}$ apart, containing one and two objects, respectively. This set will be referred to as the "region of Salins-les-Bains group".

All of the "currency-bars" examined in this study present the classic morphological characteristics of this type of object (Fig. 2). Three-quarters of the total length of the object is a long flat bar that progressively narrows and tapering towards a much thinner and rolled-up extremity (the remaining quarter). The sides show signs of hammering, which would have taken place during the final stage of manufacture. The flat bar gen- erally presents parallel edges and its thickness is usually constant, except for the extremities, where the crushing rate is more pronounced.

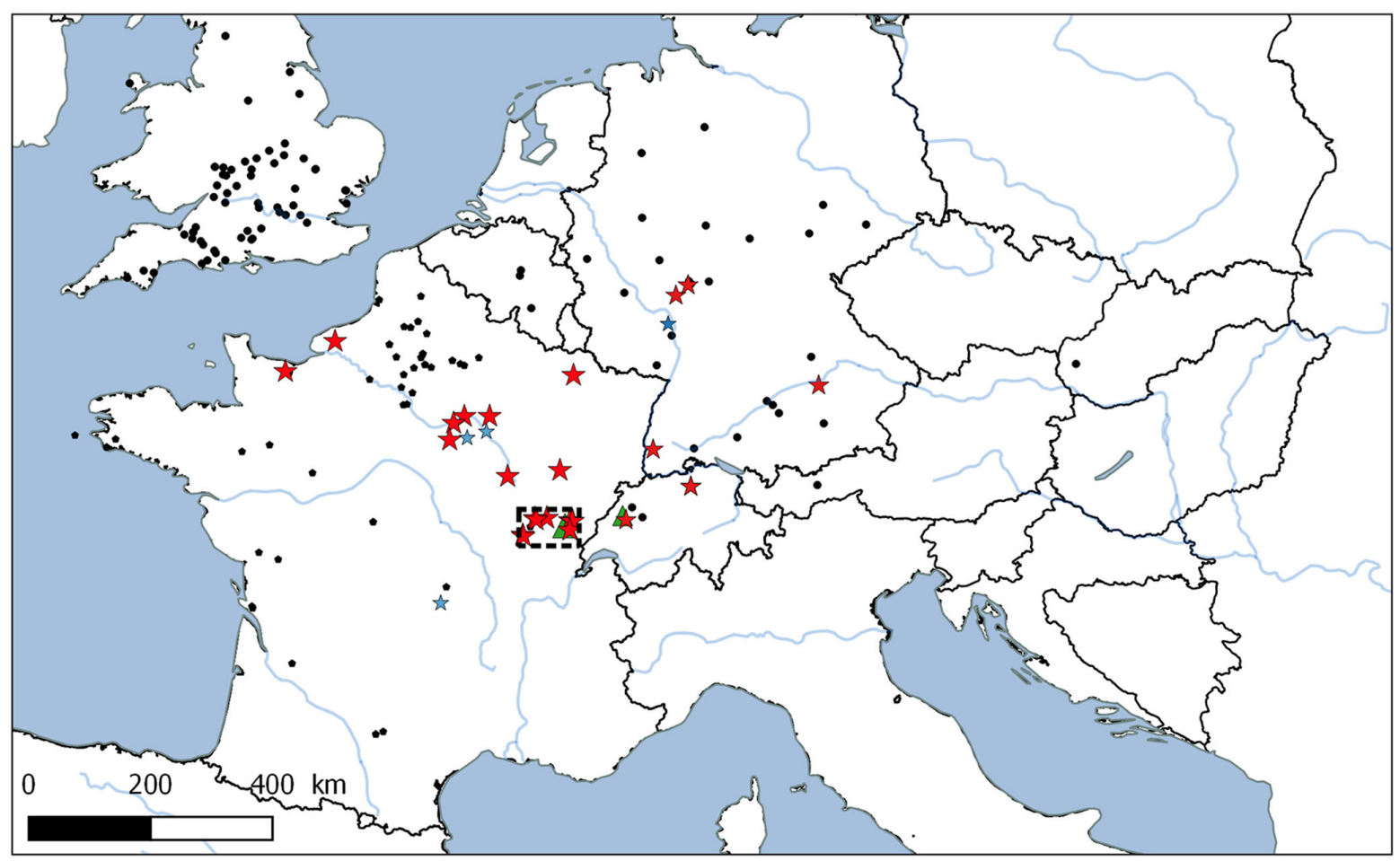

a

\section{Repartition of «currency-bars»}

$\star$ CBE1

$\star$ CBE1 ?

$\triangle \mathrm{CBE} 3$

- Other types

Studied zone, detailed in (b)

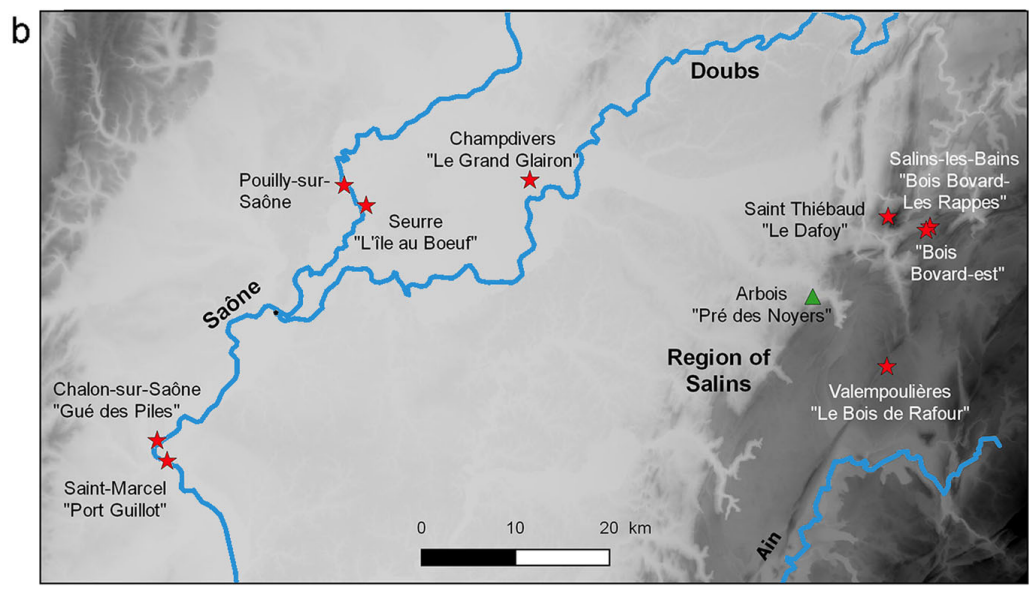

Figure 1 : a Distributionof currency bars (CB) in Europe. Locations of the CBE1 and CBE3 variants (inventoryaccordingt oBerranger2014,updated). The studied zone is indicated by the dotted rectangle. b Locations of the sites studied: the Saone River, the Doubs and the region of Salins-les-Bains 


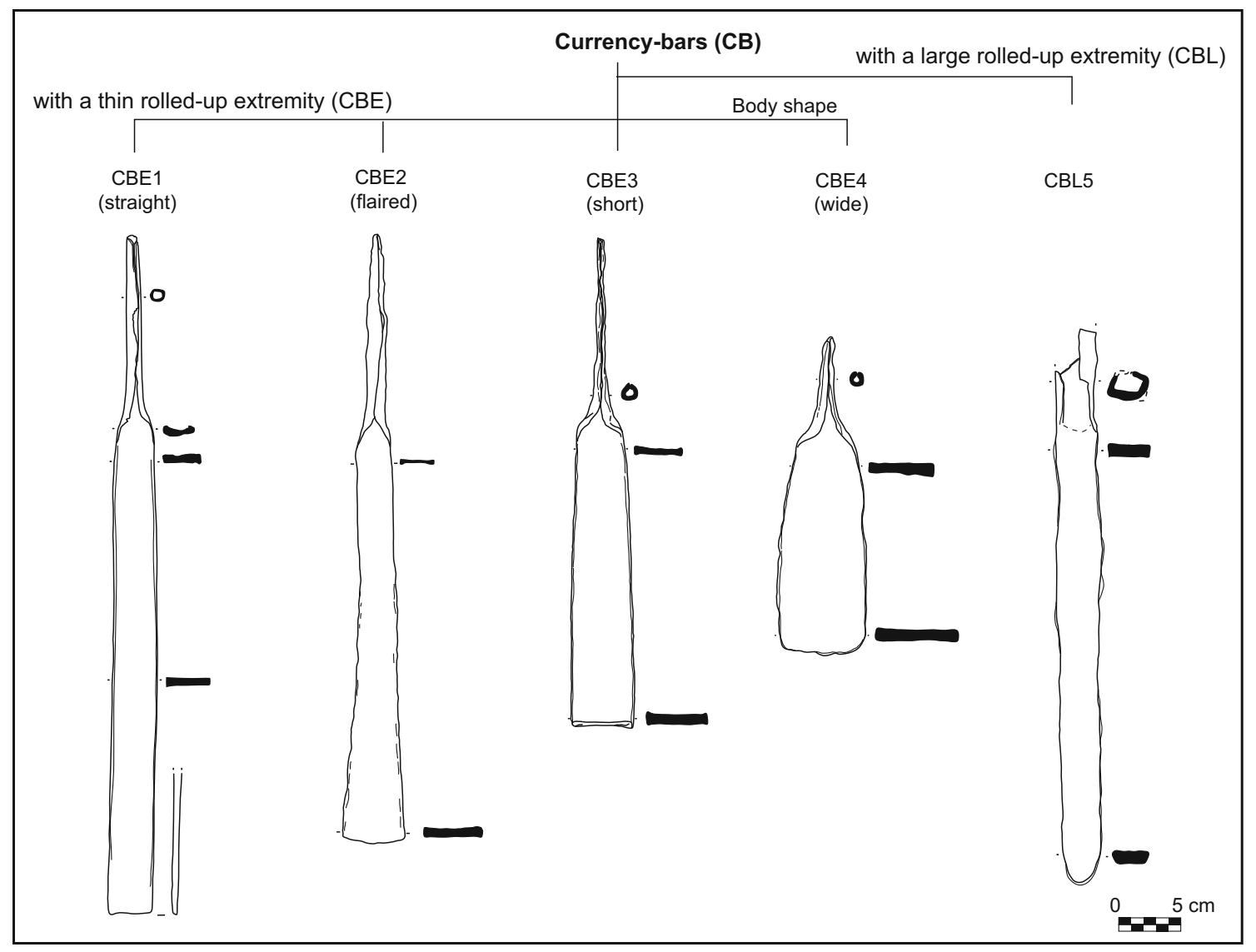

Figure 2 : Typology of currency-bars

Some 67 of the 73 bars examined (Fig. 3 and Table 1) belong to the CBE1 variant, defined in previous studies (Berranger 2014, pp. 73-75, fig. 26). From the region of Salins-les-Bains group, the two bars from Arbois and the one from Salins-les-Bains Bois Bovard-les Rappes (WPT 094-1), as well as three of the Doubs-Champdivers specimens, belong to the CBE3 variant, characterised by a short flat bar thickening towards an extremity that seems to be cut.

Overall, this set of 73 objects presented strong morpho- metrological similarities. Nevertheless, the four specimens from Valempoulières (region of Salins-les-Bains) were flat bars that were wider, longer and heavier than average. In con- trast, from the Saône River group, the Saint-Marcel specimens were lighter and thinner, while the Pouilly-sur-Saône bar was distinguished by being longer yet thinner.

\section{Methods}

Eighteen "currency-bars" representative of the different de- posits and morphological groups were examined by a multi- method characterisation to specify the nature of the ferrous alloy, the manufacturing techniques and the origin of the iron masses. Ten of these bars were also dated using the radiocar- bon method.

From the Saône River group, five bars from four discovery sites were studied. Two specimens from the Chalon-sur-Saône site were bars that fell into the water simultaneously and were subsequently stuck together by corrosion (Fig. 3). One bar was selected from the Doubs-Champdivers group. For the region of Salins-les-Bains group, 12 bars from four deposits were examined.

The objects were first analysed under a metallographic mi- croscope after cutting along a longitudinal and a semi- transverse axis (Fig. 4). The sections obtained were polished with silicon carbide paper (grades 80 to 4000 ) and then with diamond paste ( 3 and $1 \% \mu \mathrm{m})$. They were observed under a metallographic microscope before and after chemical etching (Nital $4 \%$ and Oberhoffer). The proportion of inclusions and 
the distribution of the different ranges of the iron-carbon alloy were evaluated by image analysis using microphotographs of all of the sections studied. The carbon content was determined during the metallographic analysis (content was between 0.02 and $0.9 \% \mathrm{C}$ for the corpus examined) and divided into classes using an interval of $0.2 \%$ (Bauvais et al. 2017). The surface occupied by each of these classes was then calculated by im- age analysis and expressed as a percentage (Table 2). The relative error in the surface area calculation was estimated to be around $2 \%$. The comparison of the carbon content and the homogeneity of its distribution within the objects was based on the method recently proposed by Sylvain Bauvais (Leroy et al. 2017), using the calculation of the mean surface- weighted carbon content and its standard deviation.

Bars from the Salins-les-Bains region

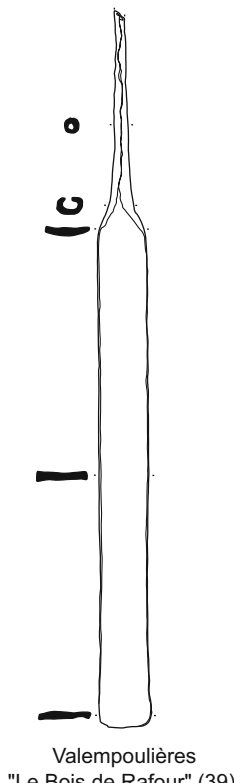

"Le Bois de Rafour" (39) VAL.01*

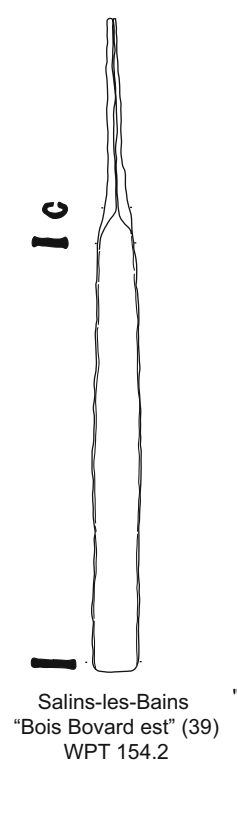

Bars from La Saône river and the Doubs

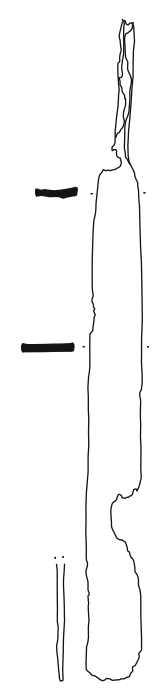

Champdivers

"Le grand glairon" (70) D.99.17.05*
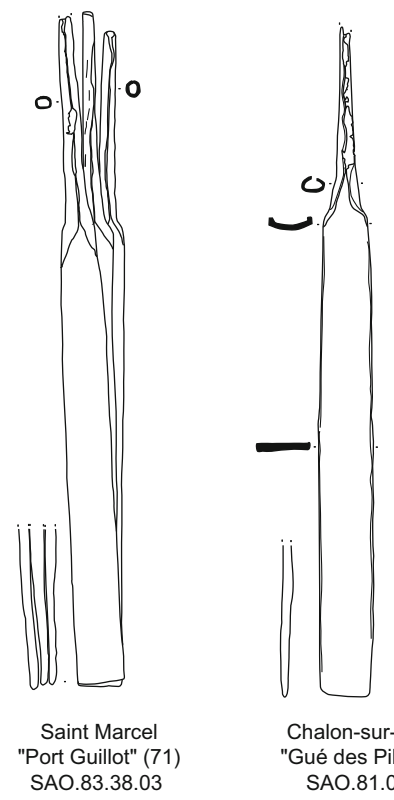

Chalon-sur-Saône "Gué des Piles" (71)
SAO.81.01.12
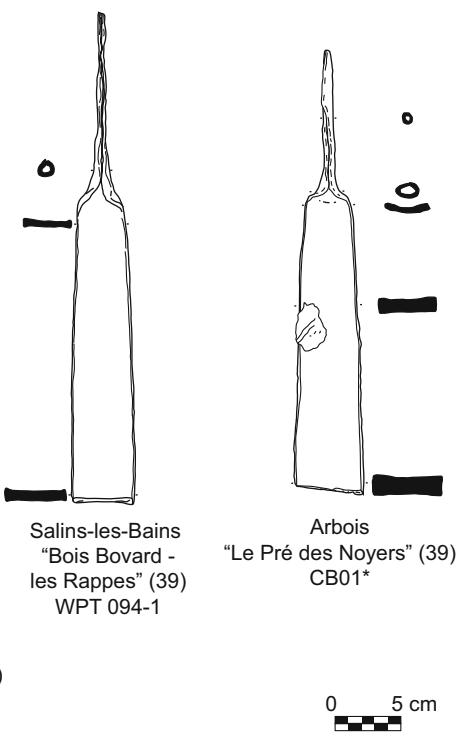

- Mont Poupet" (39)

$$
\text { SAL. } 14
$$


masses. When an object was composed of two metal masses welded together, the two sheets were analysed separately. For SAL.24 and Arbois CB01, the sheets were distinguished as SAL.24 (a) and (b) and Arbois CB01 (a) and (b). For SAL.05, SAL.08 and SAL.25, only one of the two welded sheets could be analysed.

Table 1 : nventory of the semi-products studied at the macroscopic and microscopic scales

The analysis was carried out in two stages. First, the major component elements of the inclusions were determined by energy-dispersive X-ray spectrometry (EDX) using a silicon drift detector coupled with a field-emission gun scanning elec- tron microscope (SEM-FEG, JEOL 7001-F) on the transversal crosssection studied by metallography. This set-up allowed the acquisition of large hyperspectral maps covering a repre- sentative part of the section studied. For each sample, several hundreds or thousands of inclusions were analysed.

Table 2 : Summary of the results of the metallographic analyses

\begin{tabular}{|c|c|c|c|c|c|c|c|}
\hline & \multirow[b]{2}{*}{ Site } & \multirow[b]{2}{*}{ Inventory $\mathrm{n}^{\circ}$} & \multirow[b]{2}{*}{$\begin{array}{c}\text { Proportion of } \\
\text { inclusions }\end{array}$} & \multicolumn{4}{|c|}{ Iron-carbon alloy } \\
\hline & & & & $\begin{array}{l}\text { Ferrite } \\
<0.1 \% C\end{array}$ & $\begin{array}{c}\text { Steel } \\
0.1 / 0.3 \% \\
\text { C }\end{array}$ & $\begin{array}{c}\text { Steel } \\
0.3 / 0.5 \% \\
\text { C }\end{array}$ & $\begin{array}{c}\text { Steel } \\
0.5 / 0.7 \% \\
\text { C }\end{array}$ \\
\hline \multirow{12}{*}{ 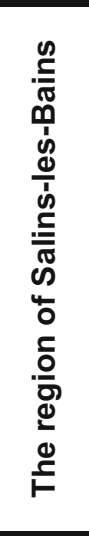 } & \multirow{8}{*}{ Saint Thiébaud } & SAL.05 & $2 \%$ & $4 \%$ & $13 \%$ & $45 \%$ & $28 \%$ \\
\hline & & SAL.06 & $4 \%$ & $43 \%$ & $1 \%$ & & $17 \%$ \\
\hline & & SAL.07 & $3 \%$ & $17 \%$ & $1 \%$ & $45 \%$ & $19 \%$ \\
\hline & & SAL.08 & $1 \%$ & $8 \%$ & $13 \%$ & $30 \%$ & $26 \%$ \\
\hline & & SAL.11 & $4 \%$ & $55 \%$ & $2 \%$ & $27 \%$ & $9 \%$ \\
\hline & & SAL.24 & $4 \%$ & $77 \%$ & $1 \%$ & $1 \%$ & $12 \%$ \\
\hline & & SAL.25 & $1 \%$ & $91 \%$ & $5 \%$ & $2 \%$ & \\
\hline & & SAL.26 & $3 \%$ & $75 \%$ & $3 \%$ & $11 \%$ & $8 \%$ \\
\hline & \multirow{2}{*}{ Valempoulières } & VAL.01 & $2 \%$ & $39 \%$ & $21 \%$ & $23 \%$ & $8 \%$ \\
\hline & & VAL.04 & $15 \%$ & $68 \%$ & $2 \%$ & $13 \%$ & $1 \%$ \\
\hline & Arbois & CB01 & $2 \%$ & $78 \%$ & $5 \%$ & $8 \%$ & $7 \%$ \\
\hline & Salins-Les-Bains & WPT-154-1 & $2 \%$ & $17 \%$ & $2 \%$ & $33 \%$ & $33 \%$ \\
\hline \multirow{5}{*}{ 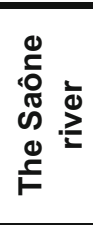 } & \multirow{2}{*}{ Chalon-sur-Saône } & $82.07 .06 \mathrm{~A}$ & $1 \%$ & $15 \%$ & $28 \%$ & $20 \%$ & $32 \%$ \\
\hline & & 82.07.06B & $2 \%$ & $52 \%$ & $20 \%$ & $13 \%$ & $9 \%$ \\
\hline & Seurre & 77.10 .07 & $2 \%$ & $93 \%$ & $2 \%$ & $1 \%$ & $1 \%$ \\
\hline & Pouilly-sur-Saône & 81.03 .01 & $2 \%$ & $75 \%$ & $4 \%$ & $16 \%$ & $3 \%$ \\
\hline & Saint Marcel & $85.01 .01 \mathrm{~B}$ & $2 \%$ & $64 \%$ & $6 \%$ & $7 \%$ & $8 \%$ \\
\hline \multicolumn{2}{|c|}{ The Doubs - Champdivers } & D.99.17.05 & $1 \%$ & $64 \%$ & $19 \%$ & $14 \%$ & $<1 \%$ \\
\hline
\end{tabular}

Smelting inclusions were identified by combining principal component analysis (PCA) and bivariate representation of non-reduced compounds (namely $\mathrm{Al}_{2} \mathrm{O}_{3}, \mathrm{SiO}_{2}, \mathrm{~K}_{2} \mathrm{O}$ and $\mathrm{CaO}$ ), as well as cross-sectional localisation following the procedures proposed by Dillmann and L'Héritier (2007) and Disser et al. (2017).

Following this selection, some 15 smelting inclusions were analysed by laser ablation-inductively coupled plasma-mass spectrometry (LA-ICP-MS) in order to determine their com- position in trace elements. This work was carried out at the Ernest-Babelon Centre (IRAMAT, Orléans, France) using a VG Plasma Quad PQXS coupled with a Nd:YAG-type laser with a quadrupled 266-nm wavelength. A total of 39 chemical elements were measured, including the series of rare earth elements. Only the trace elements with levels consistently above the limits of detection were selected for this study. The data were then transformed and normalised into logarith- mic ratios following the procedure detailed in Leroy et al. (2012). For each element, an $\mathrm{X}_{\mathrm{E}}$ value was calculated, which was used afterwards: 


$$
X_{E}=\log ([E])-\frac{1}{N} \sum_{K=1}^{N} \log \left(\left[E_{K}\right]\right)
$$

where $\left(E_{K}\right)$ is the $N$ least variable and the best measured element. In our study, the elements taken into account in the statistical analyses and the $\mathrm{E}_{\mathrm{K}}$ elements were as follows: $\mathrm{Ce}, \mathrm{Eu}, \mathrm{Gd}, \mathrm{Hf}, \mathrm{La}, \mathrm{Nb}, \mathrm{Nd}, \mathrm{Pr}, \mathrm{Sm}$, $\mathrm{Ta}, \mathrm{Tb}, \mathrm{Th}, \mathrm{U}, \mathrm{Y}$ and $\mathrm{Yb}$. This made it possible to discount the potential effects of enrichment inherent in the smelting stage (reduction in the proportion of iron in the slag in relation to the proportion of iron in the ore).

The large number of inclusions analysed and elements measured required a statistical approach (Charlton et al. 2012; Leroy et al. 2012; Dillmann et al. 2017; Disser et al. 2017; Leroy et al. 2017; Hendrickson and Leroy 2020). Thus, Agglomerative Hierarchical Clustering (AHC) using the ward aggregation algorithm to individualise clusters was combined with principal component analysis (PCA) based on Pearson correlation coefficients as a means of visualisation (XLSTAT version 19.5 software).

The chemical signatures of the 20 metal masses constitut- ing the analysed currency-bars (detailed in Online Resource 1) were examined and compared with already published data from previous analyses conducted on contemporary objects

originating from nearby regions, corresponding to the north- eastern quarter of France and the southwestern part of Germany. This corpus of 29 additional metal masses (Table 4) included bipyramidal semiproducts, crude metal masses and tires from a buried chariot found in the North- Alpine area studied during the CIPIA program (Dillmann et al. 2017). Finally, a comparison was performed with the chemical signatures of slag from different production areas from the database developed at the LAPA-CEA LMCIRAMAT-UMR5060-CNRS.

Ten objects also underwent radiometric dating of the ${ }^{14} \mathrm{C}$ entrapped in the cementite of the metallic matrix, which comes from the charcoal used during the smelting process. Recent experimental work (Leroy et al. 2020) has proven the reliability of this methodology and that the old wood effect often attributed to iron ${ }^{14} \mathrm{C}$ dating must not be over emphasised. Obviously, the date is more accurate when the fuel selected came from small trunks and young branches. The same experiment also demonstrated that iron alloys can be more reliable artefacts for dating than small unselected pieces of charcoal possibly from the oldest wood fuel loaded into the smelting furnace. 


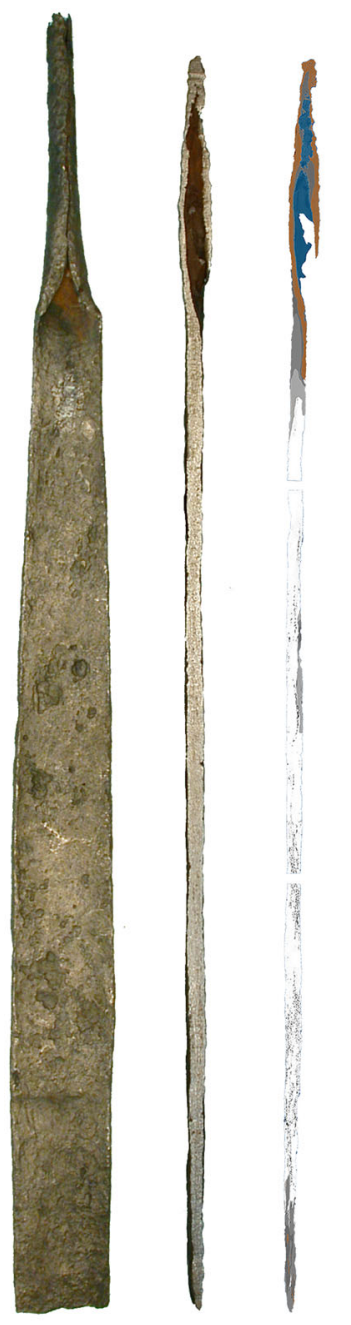

a
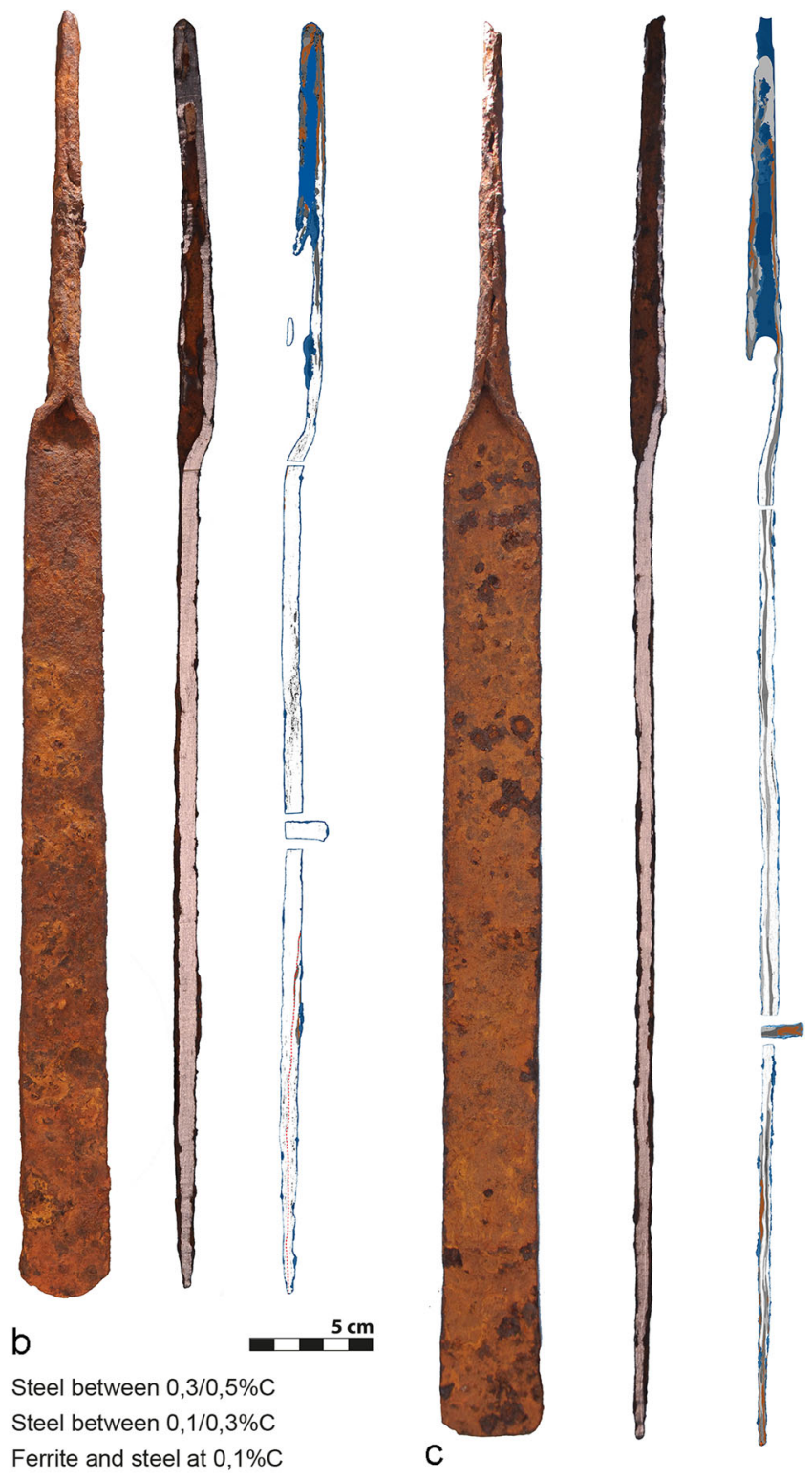

Figure 4 : Metallographi canalyses. The sections analysed: a SAO 85.01.01B (Saint Marcel - Saône River), made by simple deformation of a single mass of metal. b SAL.24 (Saint Thiébaud - region of Salins-les-Bains), with onefold. c VAL.01 (Valempoulières - region of Salins-les-Bains), manufactured by successive folding

Metallographic microscopy performed on polished cross- sections of the objects after chemical etching (Nital 4\%) en- abled the identification of the most carburised areas where particles of metal were collected by drilling (Leroy et al., 2015a, 2015b). For each object, two samples were collected for radiocarbon measurements in order to check the homoge- neity of the results. The carbon present in the metal was ex- tracted by combustion and prepared for measurement by ac- celerator mass spectrometry at the Laboratoire de Mesure du Carbone 14 (University of Paris-Saclay — Dumoulin et al., 2017; Moreau et al. 2013). The dates were calibrated with the OxCal 4.4 software (Bronk Ramsey 2009), which uses the IntCal20 calibration curve (Reimer et al. 2020).

\section{Results}

\section{Summary of the metallographic observations}

With the exception of one bar from Valempoulières (VAL.04), region of Salins-les-Bains, the entire set presented very few inclusions (proportion of impurities less than $5 \%$ of the surface area studied) with 
highly crushed inclusions. The inclusions observed were mostly multiphase and consisted of fayalite-type iron silicates $\left(\mathrm{Fe}_{2} \mathrm{SiO}_{4}\right)$, glassy phases and wüstite dendrites ( $\left.\mathrm{FeO}\right)$, in varying proportions. Some were also completely amorphous and siliceous. Rare porosities and folds were observed.

The manufacturing technique most frequently observed was shaping by simple deformation of a single metal mass (Table 2; Figs. 4 and 5). All of the bars from the Saône, the one from Doubs-Champdivers and four of the bars from the Salins-les-Bains region were shaped using this technique. For the other Salinsles-Bains objects, different manufacturing techniques were also identified. Five of the specimens from Saint-Thiébaud and Arbois were shaped by simple deforma- tion, with an assembly weld at the socket for three of them. Three bars were made by successive folds. Multiple horizon- tally superimposed and discontinuous welds, perfectly done, were found within them.

Great variability was observed within the corpus regarding the distribution of carbon (Fig. 6). The objects were distribut- ed in all classes ranging from homogeneous to very heteroge- neous, although the majority fell into the latter category. The average carbon content was more uniform; most specimens had a low carbon content, with only three from the region of Salins-les-Bains (SAL.07, SAL.05 and WPT 154-1) having medium to high carbon values.

\section{Radiocarbon dating}

The absence of precise dates for the objects led us to use radiocarbon dating for ten bars from seven different sites (Fig. 7; Table 3). The dates obtained for an object could be averaged with the R-Combine tool in Oxcal if their intervals overlapped and passed the $\mathrm{chi}^{2}$ test. This resulted in a single date for each bar with reduced uncertainty, which is of partic- ular interest for specifying the archaeological timescale for periods of strong fluctuations in ${ }^{14} \mathrm{C}$, as was the case for the Iron Age (Leroy et al. 2015a, 2015b). The bars CHAMP D.99.17.05, SAO.82.07.06A and SA0.85.01.01B did not pass the chi ${ }^{2}$ test, so no R-Combine tool was applied.

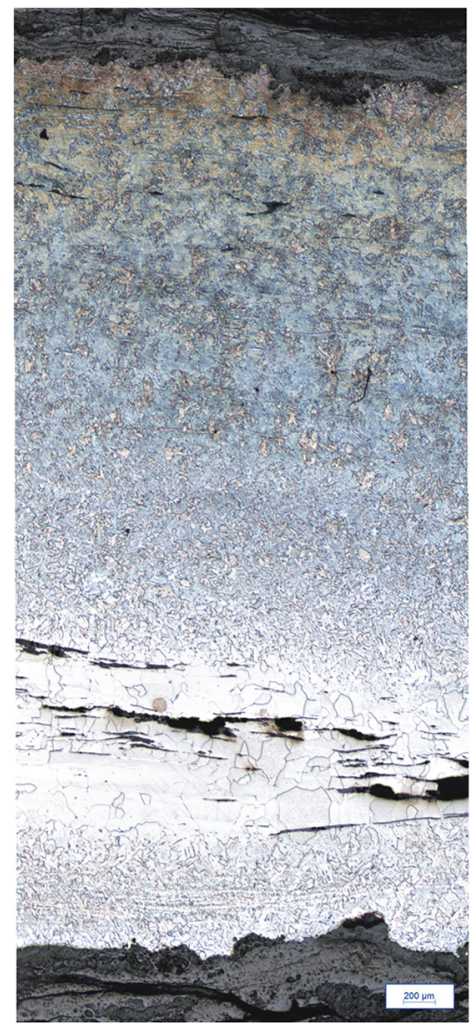

a

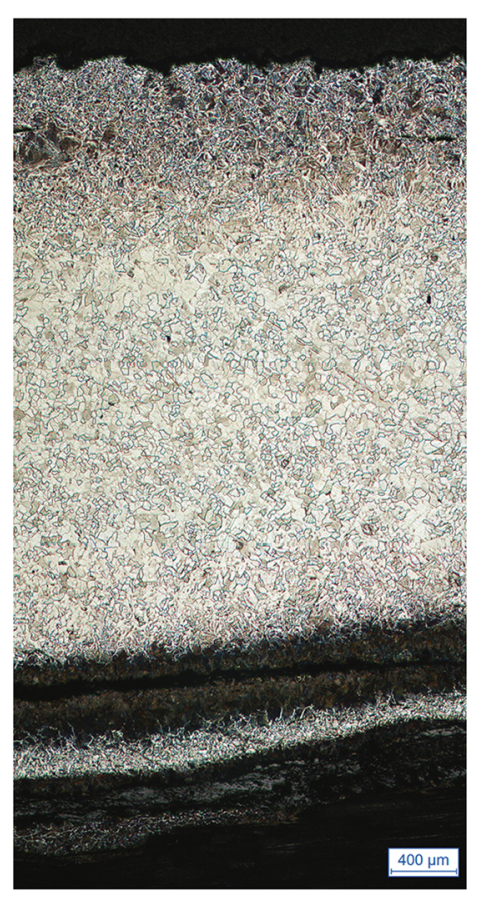

b

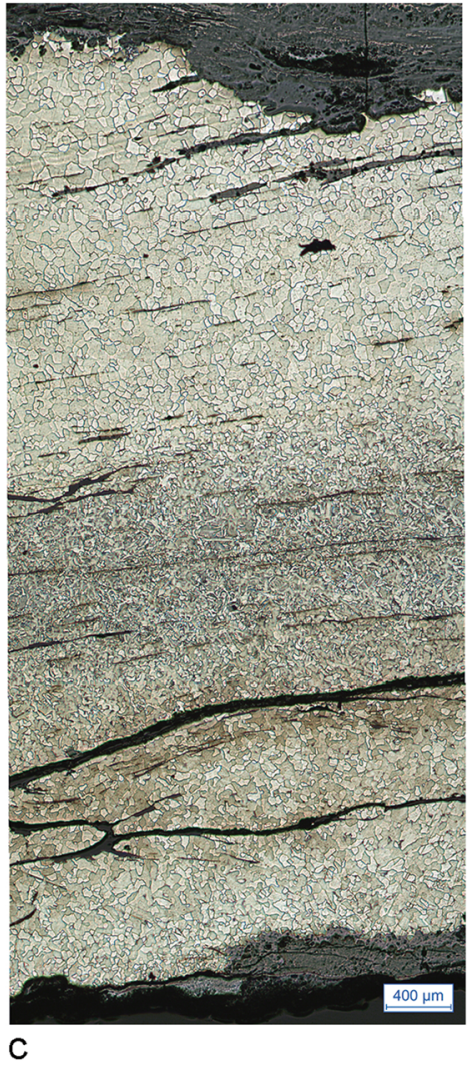


Figure 5 : Metallographic analyses. Main manufacturing techniques observed: a Salins-les-Bains WPT 154-1, section made by simple defor- mation. b Region of Salins-les-Bains, Saint Thiébaud-SAL.08, section with onefold. c Region of Salins-les-Bains, Valempoulières-VAL.01, manufactured by successive folding

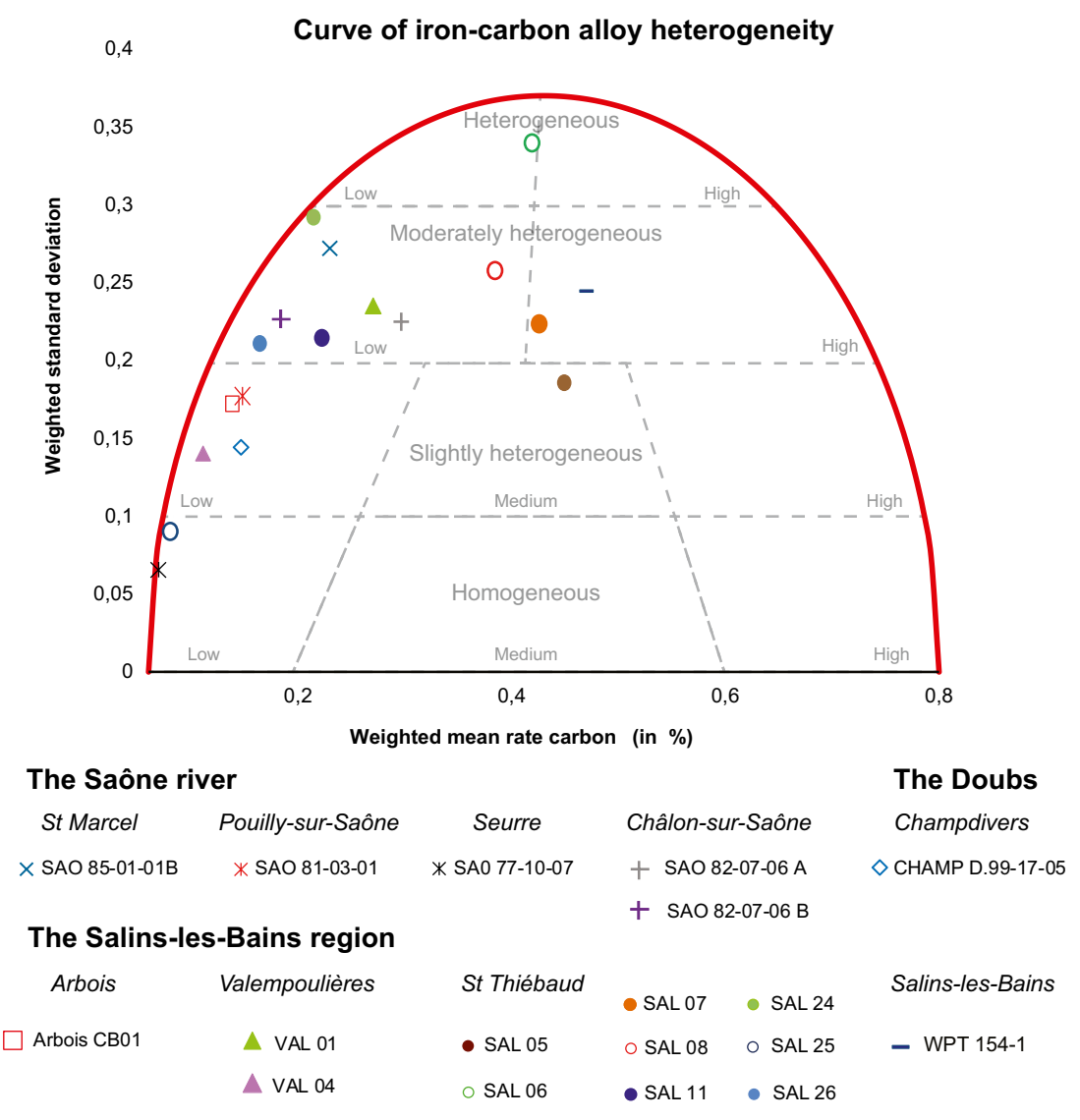

Figure 6 : Compositional domains of the iron-carbon alloy for the bars analysed (graphic from S. Bauvais-Leroy et al. 2017)

One of the dates for the bar from Doubs-Champdivers, CHAMP D.99.17.05 (2), was older than 1000 BC, which predates iron production in Europe and was therefore not retained. The second date for this same object, CHAMP D.99.17.05 (1), however, was consistent with the results ob- tained for the other bars and was retained.

For the bars from Chalon-sur-Saône (SA0.82.7.6A) and Saint-Marcel (SA0.85.01.01B), in the Saône River group, the two dates acquired for the same object showed little or no overlapping period. These dates were, however, consistent with the results obtained for the other bars and dated to the Iron Age. Their production could also date to around $400 \mathrm{cal}$. BC, i.e. a period between two consecutive plateaus in the calibration curve.

The date of Salins-les-Bains bar WPT 154-1 and the dates for the SAL.06 and SAL.08 bars from the SaintThiébaud deposit were located on the plateau of the first Iron Age, from 800 to $400 \mathrm{cal}$. BC. Also from the region of Salins-les-Bains, SAL.11 and Arbois CB01 were dated to the extreme end of this period, between 511 and 367 cal. BC.

The two bars from the Valempoulières deposit, in the re- gion of Salins-les-Bains, were attributed to distinct periods. VAL.04 was dated to a recent period relative to the rest of the corpus (between 400 and 200 cal. BC). VAL.01 was dated to around $800 \mathrm{cal}$. BC, based on the R-Combine tool. 
The chronologies obtained make it possible to attribute the majority of these bars at some point between the 8 th and 2 nd centuries BC. The imprecision of the calibrated radiocarbon dates is due to the important fluctuations of ${ }^{14} \mathrm{C}$ concentration in the atmosphere during the Hallstatt and La Tène periods, characterised by two consecutive plateaus in the calibration curve. However, the most represented time interval following the radiocarbon date is comprised between 550 and 200 cal. BC.

To summarise the chronology of each deposit, the Valempoulières deposit (region of Salins-les-Bains) is dated between 400 and $200 \mathrm{cal}$. BC according to VAL.04. The Arbois and Saint-Thiébaud deposits (region of Salins-les- Bains) date from the same time, around 400 cal. BC (accord- ing to SAL.11 and Arbois CB01), while the Salins-les-Bains "Bois Bovard" and Doubs-Champdivers deposits may date from the same or an earlier period, between 750 and 400 cal. BC. Finally, the Chalon-sur-Saône and Saint-Marcel deposits (Saône River group) could not be dated more precisely than between the 750 and 60 cal. BC for the first, and 750 and $230 \mathrm{cal}$. BC, for the second.

With the exception of VAL.01, which is older, it should be noted that the age densities of all of the objects overlapped around $400 \mathrm{cal}$. BC. It is therefore possible that all of these currency-bars were produced during this same period, even if the level of accuracy of the radiocarbon dating does not allow this hypothesis to be definitively confirmed. 


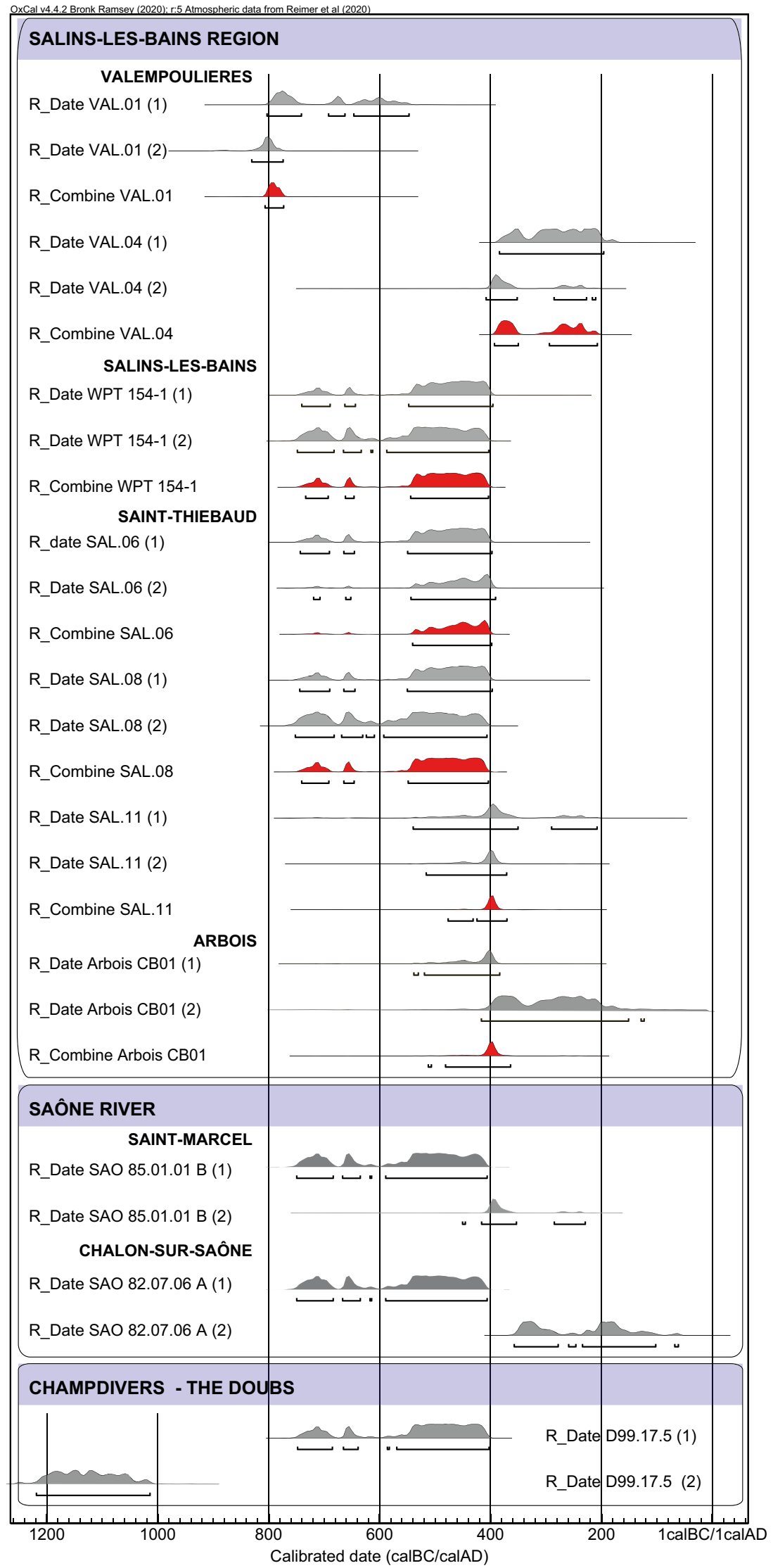

Figure 7 : Calibrated (95.4\% probability ranges) and modelled radiocarbon dates (R-Combine) obtained for the currency-bars from the Saône River, the Doubs and the region of Salins-les-Bains. Calibration and modelling in OxCal v.4.4, IntCal2020 


\section{Chemical analyses of inclusions}

The currency-bars studied here were compared with a set of objects previously studied within the framework of the ANR- DFG CIPIA program since they all date to the Iron Age and all came from the North-Alpine region. The CIPIA artefacts in- cluded bipyramidal semi-products, crude metal masses and tires from a buried chariot (Table 4). Previous work on this set of objects (Dillmann et al. 2017) suggested the existence of at least four groups of artefacts of unknown origins (named groups 1 to 4 ). The origins of three more artefacts have been determined and around twenty others do not belong to these provenance groups.

We performed Agglomerative Hierarchical Clustering (AHC) on the xij of all these different artefacts (Fig. 8) and then a PCA as a mean of visualisation (Fig. 9a, b - Online Resource 3). For the AHC, the observation of the class inertia made it possible to establish six clusters that seemed statisti- cally relevant to define (Fig. 8a). The results obtained are shown in Fig. 8 (AHC detailed in Online Resource 2). It is interesting to note that all the inclusions of a given artefact were located in the same cluster (except for one isolated in- clusion for four different objects).

An interesting preliminary observation was that the com- position of the currency-bars from the Saône River, the Doubs and the Salins-les-Bains region was sharply different from the CIPIA groups 1 to 4 . These latter artefacts correspond to clusters III, IV and V evidenced by AHC. Cluster III included objects belonging to the CIPIA groups 1 and 2, as well as some ungrouped objects from the CIPIA program (Fig. 8c). Cluster IV also included ungrouped objects from the North- Alpine region, and some from group 2 (Fig. 8c). Due to the proximity of clusters III and IV on the AHC (Fig. 8b), it can be envisaged that they constituted a unique coherent provenance group.

Cluster V contained all the objects assigned to groups 3 and 4 in the CIPIA program (Fig. 8c) and can also be interpreted as a coherent provenance group.

Cluster I corresponded to a mixture of objects from the different deposits of the Salins-les-Bains region and objects from North-Alpine regions (CIPIA) including the ones with an identified origin: the crude mass Velaine002 originated from a production area named Bajocian-Bathonian in Lorraine, another crude mass (METC114) and a tool (METC115) both found in the settlement of Hochdorf and compatible with the Black Forest area (Fig. 8c). Cluster I, therefore, did not constitute a homogeneous set.

Cluster II corresponded to a mixture of objects from the different deposits of the Salins-les-Bains region and isolated ones from the North-Alpine regions (CIPIA) (Fig. 8c). The interpretation of this cluster made up of very different objects remains complex at this stage.

On the contrary, cluster VI did not include any North- Alpine (CIPIA) objects, but only artefacts from the Saône River and the Doubs as well as the majority of the currency- bars from Saint-Thiébaud (Salins-lesBains region) (Fig. 8c). This suggested the chemical similarity of some objects from these different regions and made it possible to envisage com- mon origins for these artefacts.

We noted the proximity between cluster VI and cluster II (Figs. 8b and 9), which included a majority of the currency- bars from the Saône, all of the deposit of the Salins-les-Bains region and four CIPIA objects of undetermined origin. 
Table 4 : Inventory of the objects studied during the ANR-DFG CIPIA program (Dillmann et al. 2017) and used as a comparative set for the provenance study. Only objects with more than three analysed inclusions were taken into account

\begin{tabular}{|c|c|c|c|c|}
\hline Site & Artefact name & Dating & Type & Group of provenance or provenance \\
\hline Velaine-en-Haye "ZAC Herbue-Chalin" (France) & Velaine 002 & $H a D 3 / L T A$ & Crude mass & Bajocian-Bathonian \\
\hline Eberdingen "Hochdorf"(Germany) & METC114 & $H a D 3 / L T A$ & Crude mass & Black-Forest \\
\hline Eberdingen "Hochdorf"(Germany) & METC115 & $H a D 3 / L T A$ & Square tool & Black-Forest \\
\hline Heiligenberg-in-Heidelberg (Germany) & Heiligenberg 41-1 & Undetermined & Bipyramidal & Group 1 \\
\hline Romain (France) & Romain 1-1 & $\mathrm{HaC} / \mathrm{D}(\mathrm{Cl} 4)$ & Bipyramidal & Group 1 \\
\hline Durrenentzen (France) & Dur 40-1 & $\mathrm{Ha} C / \mathrm{D}(\mathrm{Cl} 4)$ & Bipyramidal & Group 1 \\
\hline Xirocourt (France) & Xir 1-1 & $\mathrm{Ha} C / D(C 14)$ & Bipyramidal & Group 2 \\
\hline Xirocourt (France) & Xir $1-2$ & $\mathrm{HaC} / \mathrm{D}(\mathrm{Cl} 4)$ & Bipyramidal & Group 2 \\
\hline Marsal (France) & Marsal 3-2 & $\mathrm{Ha} D 2 / D 3$ & Bipyramidal & Group 2 \\
\hline Durrenentzen (France) & Dur 3 & $\mathrm{HaC} / \mathrm{D}(\mathrm{Cl} 4)$ & Bipyramidal & Group 2 \\
\hline Eberdingen "Hochdorf"(Germany) & METC113 & $\mathrm{Ha} D 3 / L T A$ & Tire & Group 2 \\
\hline Marainville-sur-Madon "Sous le chemin de Naviot" (France) & Marain 2 & $H a D 1$ & Tire & Group 3 \\
\hline Marainville-sur-Madon "Sous le chemin de Naviot" (France) & Marain 4-2 & $H a D 1$ & Tire & Group 3 \\
\hline Marainville-sur-Madon "Sous le chemin de Naviot" (France) & Marain 4-1 & $H a D 1$ & Tire & Group 4 \\
\hline Köngen (Germany) & Köngen & $\mathrm{Ha} C / D 1$ & Tire & Group 4 \\
\hline Altheim-Heiligkreuztal "Hochmichele" (Germany) & Hoch Grab 6 & Ha D1 & Tire & None \\
\hline Marainville-sur-Madon "Sous le chemin de Naviot" (France) & Marain 1 & Ha D1 & Tire & None \\
\hline Heiligenberg-in-Heidelberg (Germany) & Heiligenberg 42 & Undetermined & Bipyramidal & None \\
\hline Renningen (Germany) & Renningen & Undetermined & Bipyramidal & None \\
\hline Waiblingen (Germany) & Waiblingen & Undetermined & Bipyramidal & None \\
\hline Marsal (France) & Marsal 1-1 & Ha D2/D3 & Bipyramidal & None \\
\hline Marsal (France) & Marsal 1-2 & Ha D2/D3 & Bipyramidal & None \\
\hline Marsal (France) & Marsal 3-1 & Ha D2/D3 & Bipyramidal & None \\
\hline Farebersviller (France) & Far 1-1 & Ha C/D (C14) & Bipyramidal & None \\
\hline Farebersviller (France) & Far 1-2 & $\mathrm{Ha} \mathrm{C/D} \mathrm{(C14)}$ & Bipyramidal & None \\
\hline Durrenentzen (France) & Dur 48-1 & $\mathrm{Ha} \mathrm{C/D} \mathrm{(C14)}$ & Bipyramidal & None \\
\hline Durrenentzen (France) & Dur 6 & $\mathrm{Ha} \mathrm{C/D} \mathrm{(C14)}$ & Bipyramidal & None \\
\hline Eberdingen "Hochdorf"(Germany) & METC117 & Ha D3/LT A & Tire (nail) & None \\
\hline Eberdingen "Hochdorf"(Germany) & METC118 & Ha D3/LT A & Square tool & None \\
\hline
\end{tabular}

Objects belonging to a provenance group in italic 

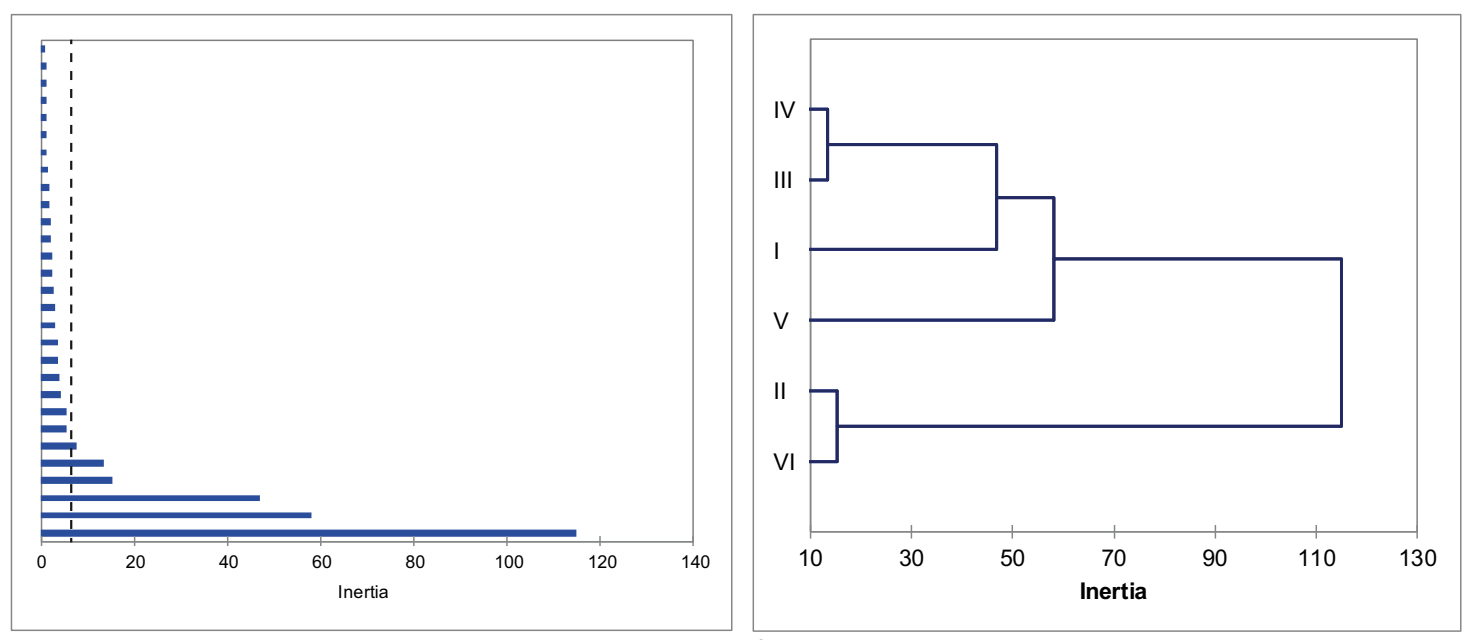

b

\begin{tabular}{|c|c|c|c|c|c|}
\hline \multicolumn{6}{|c|}{ Cluster } \\
\hline 1 & ॥I & III & IV & $\mathrm{V}$ & $\mathrm{VI}$ \\
\hline Arbois CB01 (a) & Arbois CB01 (b) & Dur 40-1 (CIPIA gpr1) & Dur 3 (CIPIA gpr2) & Köngen (CIPIA grp4) & SAL 06 \\
\hline Dur $6\left(1\right.$ incl $\left.^{\circ}\right)$ & Dur 48-1 & Far $1-1\left(1 \mathrm{incl}^{\circ}\right)$ & Hoch Grab 6 & Marain 2 (CIPIA grp3) & SAL 11 \\
\hline Far $1-2$ & Renningen & Heiligenbe 41/1 (CIPIA gpr1) & Marain 1 & Marain 4-1 (CIPIA grp4) & SAL 24 (a) \\
\hline Marsal 1-1 & SAL $11\left(1\right.$ incl $\left.^{\circ}\right)$ & Heiligenberg 42 & Marsal 3-2 (CIPIA - grp2) & Marain 4-2 (CIPIA grp3) & SAL 24 (b) \\
\hline Marsal 1-2 & Dur 6 & Marsal 3-1 & METC113 (CIPIA gpr2) & & SAO 81-03-01 \\
\hline METC114 (Black-Forest) & Far 1-1 & METC117 $\left(1 \mathrm{incl}^{\circ}\right)$ & & & SAO 82-07-06 A \\
\hline METC115 (Black-Forest) & SA0 77-10-07 & METC118 & & & SAO 82-07-06 B \\
\hline METC117 & SAL 05 & Romain 1-1 (CIPIA grp1) & & & CHAMP D.99-17-05 \\
\hline SAL 08 & SAO 85-01-01 B & Waiblingen & & & \\
\hline SAL 25 & SAL 07 & Xir 1-2 (CIPIA grp 2) & & & \\
\hline SAL 26 & VAL 01 & Xir 1-1 (CIPIA grp2) & & & \\
\hline VAL 04 & WPT 154-1 & & & & \\
\hline Velaine 002 (Bajocian-Bath.) & & & & & \\
\hline
\end{tabular}

Figure 8: AHC carried on the xij of the currency-bars (in bold) from the Saône River, the Doubs, the region of Salins-les-Bains and a comparative set of objects from the North-Alpine region (CIPIA corpus): a inertia jump permitting isolation of six different clusters. $b$ Organisation of clusters resulting from the HAC. $c$ Repartition of the objects into the six clusters. The currency-bars under study are underlined in bold. For the CIPIA objects, their initial provenance groups are mentioned (Dillmann et al. 2017, also see Table 4) 


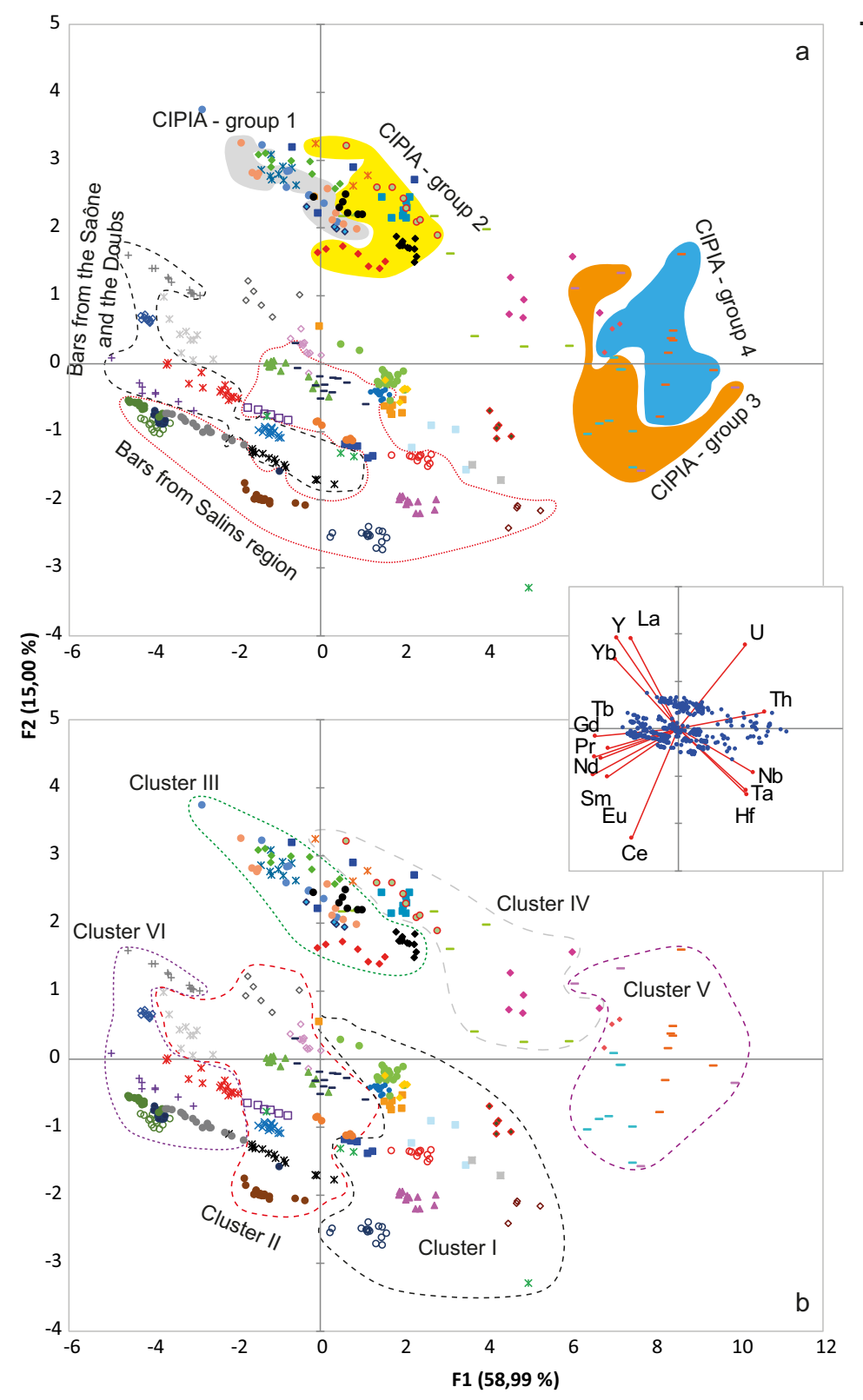

\section{The Salins les-Bains region}

\begin{tabular}{|c|c|}
\hline Arbois & St Thiébaud \\
\hline Arbois CB01 (a) & - SAL 05 \\
\hline$\square$ Arbois CB01 (b) & - SAL 06 \\
\hline Salins-les-Bains & - SAL 07 \\
\hline - WPT 154-1 & ○ SAL 08 \\
\hline Valempoulières & - SAL 11 \\
\hline$\triangle$ VAL 01 & - SAL 24 (a) \\
\hline$\triangle$ VAL 04 & - SAL 24 (b) \\
\hline & ○ SAL 25 \\
\hline & - SAL 26 \\
\hline
\end{tabular}

The Saône river

St Marcel Pouilly-sur-Saône

$\times$ SAO 85-01-01B $\quad *$ SAO 81-03-01

Seurre Châlon-sur-Saône

* SA0 77-10-07 + SAO 82-07-06 A

+ SAO 82-07-06 B

\section{The Doubs}

Champdivers

$\diamond$ CHAMP D.99-17-05

Objects from the North-Alpine region (CIPIA corpus)

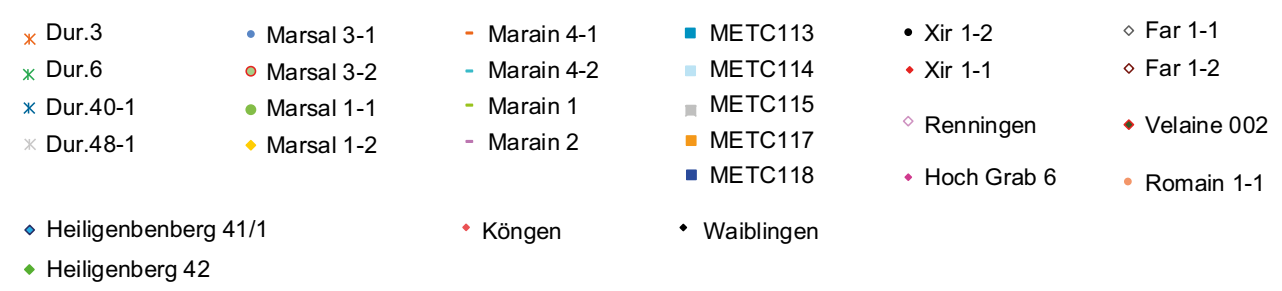

Figure 9: PCA carried out on the xij of the currency-bars from the Saône River, the Doubs, the region of Salins-les-Bains and a comparative set of objects from the North-Alpine region (CIPIA corpus): a the provenance groups from the CIPIA study (Dillmann and al. 2017) and the geograph-ical groups of the present study. $b$ The clusters resulting from the AHC (refer to Fig. 8)

Studying the provenance of the different deposits helps in interpreting the constitution modalities of each of the deposits. For the Chalon-sur-Saône deposit (Saône River), bars SA0.82.07.06 A and B (which were simultaneously submerged in water) were both distributed in cluster VI, sug- gesting a common 
provenance. On the contrary, in Valempoulières (region of Salins-les-Bains), the two bars studied were very different in terms of chemistry and were distributed in different clusters, thus suggesting different ori- gins. This diversity of supply also characterised the Saint- Thiébaud (region of Salins-les-Bains) deposit, which com- prised 26 bars, of which the eight bars analysed were distrib- uted across three distinct clusters.

Concerning the objects made up of two distinct metal masses, two cases were noted. The two metal masses (SAL.24 (a) and SAL.24 (b)) constituting SAL.24 (Saint- Thiébaud deposit) were grouped in the same cluster and were very close on the dendrogram (Online Resource 2), suggesting the same provenance. However, the two metal masses of the Arbois currency-bar (Arbois CB01 (a) and CB01 (b)) were distributed across two different clusters, which possibly indi- cates distinctly different origins.

Finally, the chemical characteristics of the slag inclusions in the metal of the different objects were compared with the available analyses for production areas in north-eastern France and south-eastern Germany (Dillmann et al. 2017). However, none of these areas was found to have a chemical signature compatible with that of the objects.

\section{Discussion}

Figure 10 summarises all of the results obtained in this study. Production trajectories: from raw metal masses to

\section{semi-products}

The interdisciplinary study carried out on the corpus of currency-bars provided information about metal supplies and the nature of their transformations in the forge. This data also provided information about trade and production conditions The results of the chemical analyses indicated that supplies came from diverse sources. Thus, several different provenance groups were identified for objects making up a single deposit, such as in Saint-Thiébaud and Valempoulières, in the Salins- les-Bains region.

The currency-bars discovered in the Saône River, the Doubs and the Salins-les-Bains region were located far from the known major production centres of this period. Important centres of production, including several dozen smelting work- shops, were known in France, in the region of Le Mans, and in central France (Berranger, Bauvais 2020). But up until the 2nd c. BC, the production of iron (bloomery process) was widely dispersed over the northern half of France and southern half of Germany, and may have been organised around small units including isolated furnaces (Berranger, Bauvais 2020; Dillmann et al. 2017 fig. 2).

Given this framework, the multiplicity of origins of the metal composing the studied currency-bars could be explained either by supplies from several large and remote production centres or by the existence of a local, small-scale and scattered production, still unlocated. This chemical variability could also be the result of the way in which these deposits were constituted. Several actors (communities or possibly individ- uals) may have participated in gathering the iron necessary for the constitution of these deposits, prior to the shaping of the bars themselves, by sourcing their supplies from different ex- change networks.

This same mode of organisation has already been ob- served for the Iron Age (Bauvais et al. 2017) and is regu- larly documented in iron metallurgy, during both Antiquity (Pagès et al. 2011) and the mediaeval period (Disser et al. 2016). It induced specialisation of the different actors of the "chaîne opératoire" (smelting/bloomsmithing/smithing stages), and in some cases revealed that the supply was not solely confined by the geographical proximity of the re- sources (Disser et al. 2016). 


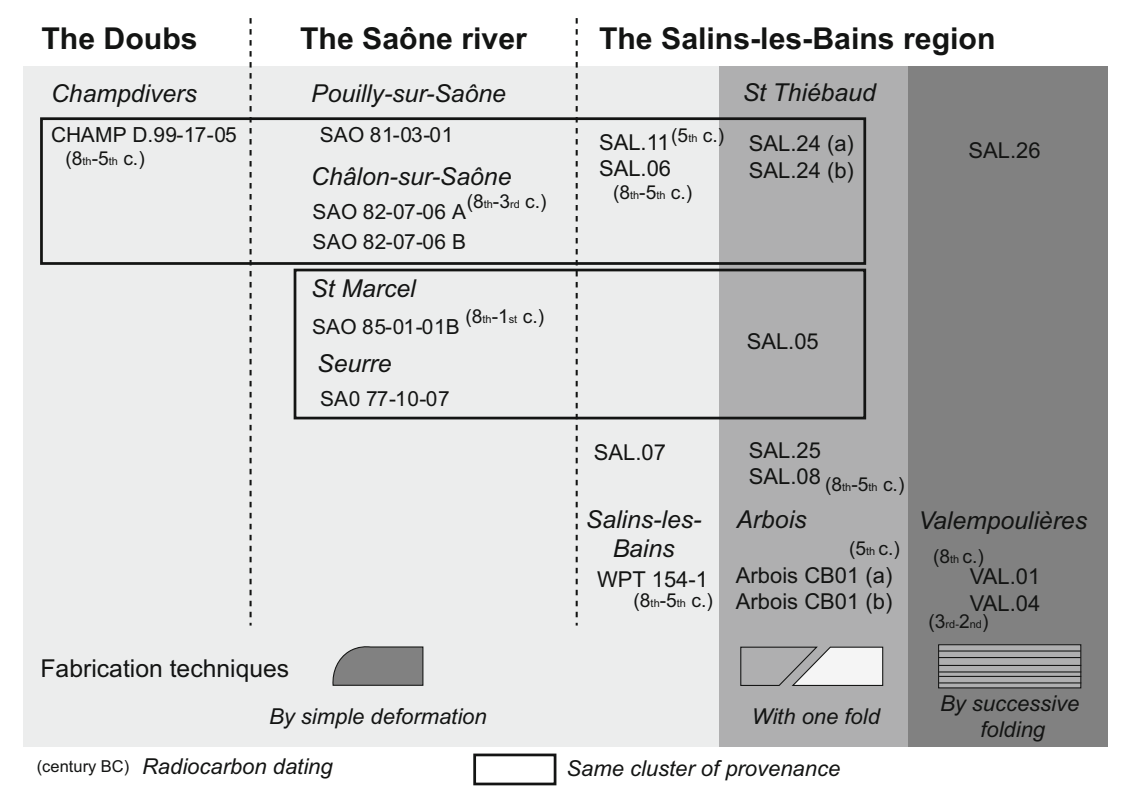

Figure 10 : Diagram summarizing all of the results obtained for the manufacturing techniques, archaeological timescale and groups of origin of the currency-bars studied

Groups of common origins for the bars from the Saône River and the Doubs and for certain bars from the Salins-les- Bains region highlight the possibility of a supply from the same sources of production. Other work has already pinpointed the sharing of expertise within these same regions, particularly based on the analysis of the "chaîne opératoire" of manufacture for copper-based alloy timbale fibulae (Cararra et al. 2013). The typology of the metal objects also under- scores the integration of these regions within the same trade networks (Dubreucq 2013, pp. 302-308). More precisely, they indicate privileged contacts with Champagne, Burgundy and Switzerland, and, on a wider scale, with Northern Italy and Central Europe. At this stage, comparisons with the iron production areas of central and eastern France and south-western Germany, for which chemical data are available, have not identified the provenance of the raw iron.

Although the metal used for these bars was heterogeneous in terms of quality and provenance, the manufacture of these semi-products was standardised. The typological and metro- logical characteristics of the samples studied here revealed compliance with common manufacturing standards. Moreover, all of the bars analysed were very well refined. Although inherent to obtaining a thin, flat product, great care was also given to the shaping, a characteristic probably asso- ciated with these types of semi-products.

Greater similarities in morphology, metrology and even manufacturing techniques were noted for objects coming from the same deposit. This was also the case for deposits integrat- ing metal products of different origins and qualities, as in Valempoulières, Saint-Thiébaud and Chalon-sur-Saône. The metal masses used, probably circulated in a raw form, possibly over long distances, before being transformed into semi-products. The morphological homogeneity of the studied objects may thus indicate the presence of forges within this sector, which constitutes the heart of a concentration of CBE1- and CBE3-type semi-products.

\section{Constitution modalities of the deposits}

Little information is available about the life of these currency- bars after they were forged. Were they immediately deposited after manufacture? Or did they circulate first? The surface condition of these objects provided no additional information.

For the objects found in the Saône, the absence of other clues made it impossible to determine their period of immer- sion more precisely than prior to the 2nd century BC. 
The chronology obtained for the objects from the Salins- les-Bains region spans both Iron Ages (8th-1st c. BC). Nevertheless, the very similar dates, between 512 and 365 cal. BC, obtained for one bar from SaintThiébaud and another from Arbois, could correspond to the periods during which these deposits were established. The Valempoulières and Bois Bovard deposits in the Salins-les-Bains region may have been made during this same period, even though the age densities are spread out over longer timeframes. In each case, these groups of objects, discovered in the same area of Salins- les-Bains, resulted from the same forging tradition.

These discoveries were made in a region with two key advantages: the exploitation of local salt resources and the control of transportation routes linking the Jura, the Swiss plateau, Northern Italy, the Rhone valley and the plains of the Saône. The emergence of aristocratic lineages manifesting their power in tumuli containing rich objects, and in some cases even a chariot, has been documented since the Bronze Age (Piningre and Ganard 2004, pp. 393-398). This was ac- companied by the discontinuous occupation, at Salins-les- Bains, of the fortified Camp du Château and the establishment of series of deposits of metal objects, corresponding to possi- ble territorial markers during the Bronze Age (Gauthier and Piningre 2016). For the Hallstatt D2-D3 and La Tène A, the proximity of tumular necropolises and the discovery of Mediterranean imports at this residential site seem to corre- spond to the model of aristocratic residences of the first Iron Age (8th-4th c. BC). It is tempting to link the last days of the protohistoric occupation of the Camp du Château during the La Tène A sub-period with the establishment of these deposits of currency-bars, at least two of which were dated to around $400 \mathrm{cal}$. BC. These deposits could then represent the last con- temporary ostentatious manifestations of the profound eco-nomic and social changes that took place during the 5 th to 4 th centuries BC.

\section{From a chronological hiatus to a commemorative function}

At Doubs-Champdivers, the bar dated from the first Iron Age (8th-5th c. BC) is one of the oldest iron products in this de- posit (Daubigney et al. 2007). Two hypotheses merit consid- eration. Possibly, this bar arrived in this wetland around $400 \mathrm{cal}$. BC with some other elements attributed to the same La Tène A sub-period. Yet, the rarity of the latter and the abun- dance of elements attributed to La Tène B2/C1 and especially La Tène $\mathrm{D}$ in this deposit also lead us to consider that this a priori archaic object may have been abandoned later, during the late Iron Age (2nd-1st c. BC). Indeed, deposits of artefacts belonging to different periods are quite regularly encountered in Gaulish sanctuaries (Lejars 2019; Nouvel and Thivet 2019).

The case of the VAL.01 bar (Valempoulières deposit in the region of Salins-les-Bains), dated around 800 cal. BC, also deserves further discussion. This object was found along with three other identical bars, including VAL.04 attributed to a more recent period (394-208 cal. BC). The morphological and metrological similarities of these bars indicate that they were shaped according to the same standard, synchronously, probably around the 4th to 3rd centuries BC according to the most recent date for VAL.04.

VAL.04 and VAL.01 stand out among the objects studied for their specific shaping by successive folds - a technique that permits homogenising a product while "forming" its shape. This characteristic leads us to consider the hypothesis of the recycling of an older iron object, reworked in a forge. Given that VAL.01 consists of a single metal mass, it would have been a large object produced around the 8th century BC, a period during which the spread of iron, far from being quan- titatively significant, belonged exclusively to the aristocratic sphere (Brun et al. 2009, p. 481).

Since the dating of VAL.01 is much earlier than the period during which currency-bars were being produced, it may il- lustrate the use of older, massive objects, possibly with a spe- cific symbolic value for their fabrication.

A re-evaluation of the archaeological timescale of Iron Age semi-products

The radiocarbon dating carried out here makes it possible to reconsider the archaeological timescale of semi-products from the Iron Ages. 
A recent review documents the discoveries of currency- bars in dated contexts (Berranger and Fluzin 2012; Berranger 2014, pp. 120-122, fig. 41), including 50 sites (European scale) of which only 30 provided precise chrono- logical data. These contexts were dated between the 3rd cen- tury and the second half of the 1st century BC.

Here, the most represented time interval following the ra- diocarbon date is comprised between 550 and $200 \mathrm{cal}$. BC. The results of the radiocarbon dating situate the entire corpus earlier than the archaeological contexts. Only VAL.04, com- ing from the region of Salins-les-Bains, could be dated at the earliest in the 3rd century BC, like certain archaeological con- texts. This was also the case for the bars from the Saône River, SAO.82.07.06A and SA0.85.01.01B, but their radiocarbon dating was imprecise, between 751 and $229 / 60$ cal. BC. The dating of the other bars situates them before $400 \mathrm{cal}$. BC (Fig. 7, Table 2), and for Arbois CB01 and SAL.11 precisely be- tween 512 and 365 cal. BC.

A chronological gap between the radiocarbon dating of semi-products and the dating of archaeological contexts is thus noted. However, the former method dates the charcoal used during the production of the metal masses, while the contexts document their period of abandonment. In most cases, the contexts in which currency-bars were discovered are indicative of the removal of these objects from ordinary economic cycles: places of ceremonial practices, deposits in wetlands, sanctuaries or intentional deposits in residential sites.

Online Resource 4 lists the archaeological contexts, on a European scale, presenting CBE1- and CBE3-type bars. Most of the sites providing tighter chronological data for these bars date from the $3 \mathrm{rd} \mathrm{c}$. BC, and the La Tène B2/C1 period (Berranger 2014, fig. 41 - see Online Resource 4; France: Le Chêne, Bourguignonlès-Morey, Marin-Epagnier in Switzerland, Ulversheim in Germany, etc.). The dating of these archaeological contexts is consistent with the most re- cent dates provided by the radiocarbon method. The sites at- tributed to later periods that produced CBE1 and CBE3 types were occupied over long periods and were either sanctuaries or deposits in settlements.

For the period from the 2nd to the 1st centuries BC, an increasing number of well-dated archaeological contexts have revealed currency-bars (Berranger and Fluzin 2012; Berranger 2014, pp. 120-122, fig. 41), confirming their continued circu- lation until the end of the second Iron Age (late 1st c. BC). In most cases, however, these are no longer semi-products of the CBE1 and CBE3 types. They are lighter in weight (about a hundred grams) and the quality of execution is particularly high (shaping by folding, peripheral carburising, ibid.). Called "socket bars" and essentially attributed to the BAD1 type, they are mainly concentrated in the Paris Basin in France and found in sanctuaries, or in southern part of England (Crew 1994) where they are often discovered close to hill-fort ram- part or settlement boundaries ditches (Hingley 1990). Data from archaeological contexts also make it possible to link other types of currencybars to the end of this period. For example, those of the CBL5 type, characterised by a much wider rolled extremity, were known in the north-western half of Gaul or with slight morphological variations in England, where some of them were designated as "plough-share" type (Crew 1994).

Other categories of semi-products circulated during the Iron Ages, including hooked billets and bipyramidal bars. Their typology and archaeological timescale, based on the study of their discovery contexts, have been previously stud- ied (Berranger and Fluzin 2012; Berranger 2014, pp. 114- 124, figs. 16 and 42). The hooked billets, of which only a small number of specimens have survived to this day, were in use over a long period from the first Iron Age to the Roman period.

Recently, new data concerning bipyramidal bars has been provided by carrying out absolute dating (Berranger 2014, p. 147; Bauvais et al. 2015; Bauvais et al. 2017; Berranger et al. 2017). This has made it possible to definitively attribute bipy- ramidal semi-products to the first Iron Age and thus to rule out the hypothesis sometimes put forward, on the basis of poorly established contexts, of a Roman dating (Kleeman 1981). Indeed, the ensemble of the dates covers the entire first Iron Age plateau (Fig. 11). The Dur.1 specimen dates back to the very beginning of the period around $800 \mathrm{cal} . \mathrm{BC}$, but most of the age densities determined by the R-Combine tool are between 800 and $500 \mathrm{cal}$. BC, i.e. during a period older than that recognised for types CBE1 and CBE3. 


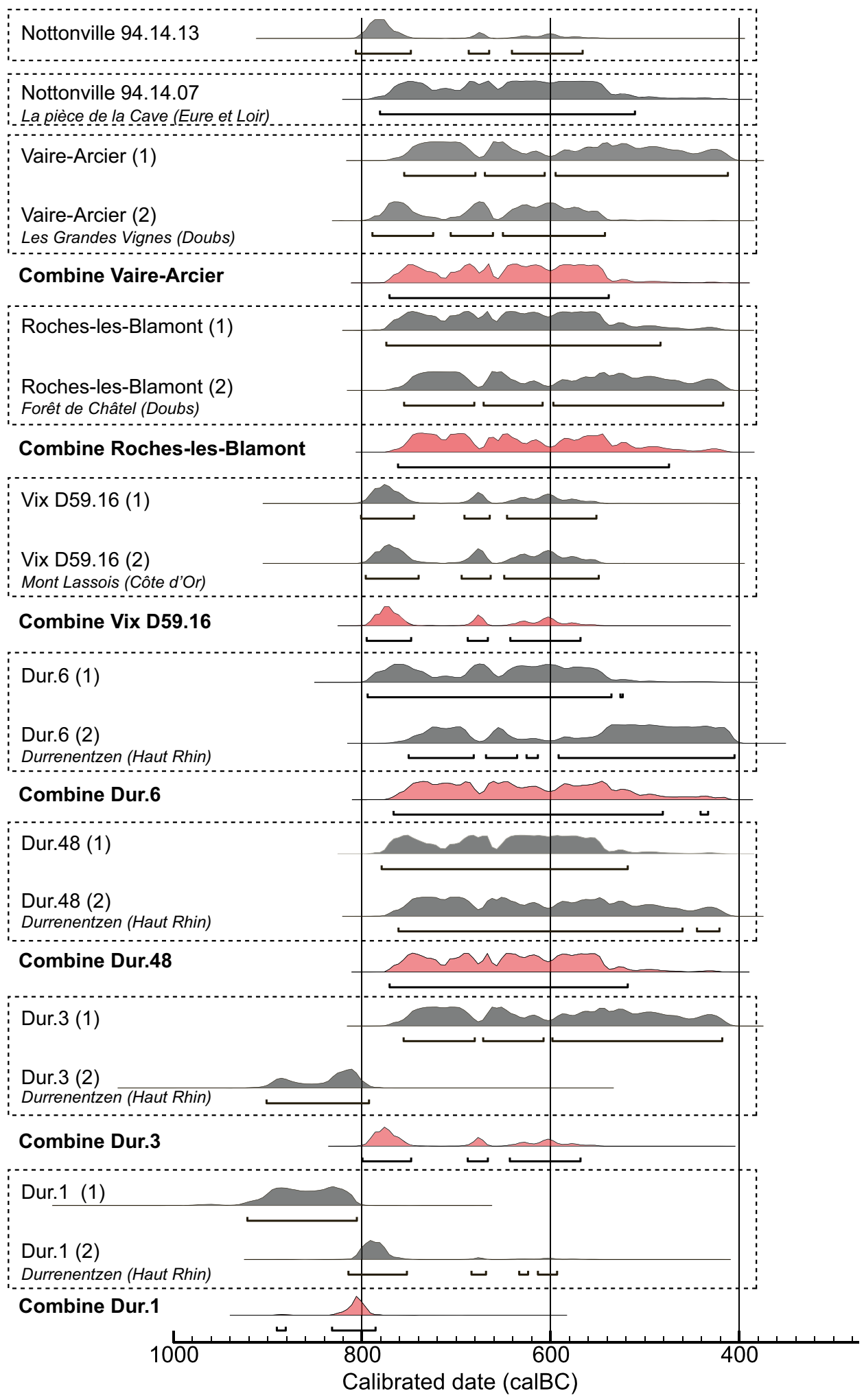

Figure 11 : Calibrated(95.4\% probability ranges) and modelled radiocarbon dates (R-Combine) obtained for the bipyramidal semi-products. Calibration and modelling in OxCal v.4.4, IntCal2020

In light of these newly acquired results, a typochronology of semi-products can be proposed according to three main periods (Fig. 12). The hypothesis that bipyramidal semi- products are older than currencybars remains valid (Berranger and Fluzin 2012). However, the period of use of these two categories of semi-products must be dated back further, and a possible overlap of these periods considered. The 
bipyramidal bars would probably be related to the older period of the first Iron Age, between 800 and 500 cal. BC. Among the currency-bars, the CBE1 and CBE3 variants would have appeared first and would mainly date to a period between 550 and $200 \mathrm{cal}$. BC. The last two centuries BC would have witnessed the appearance of new forms of curren- cy-bars, such as type CBL5 and socket bars. The regional character of these variants should be noted.

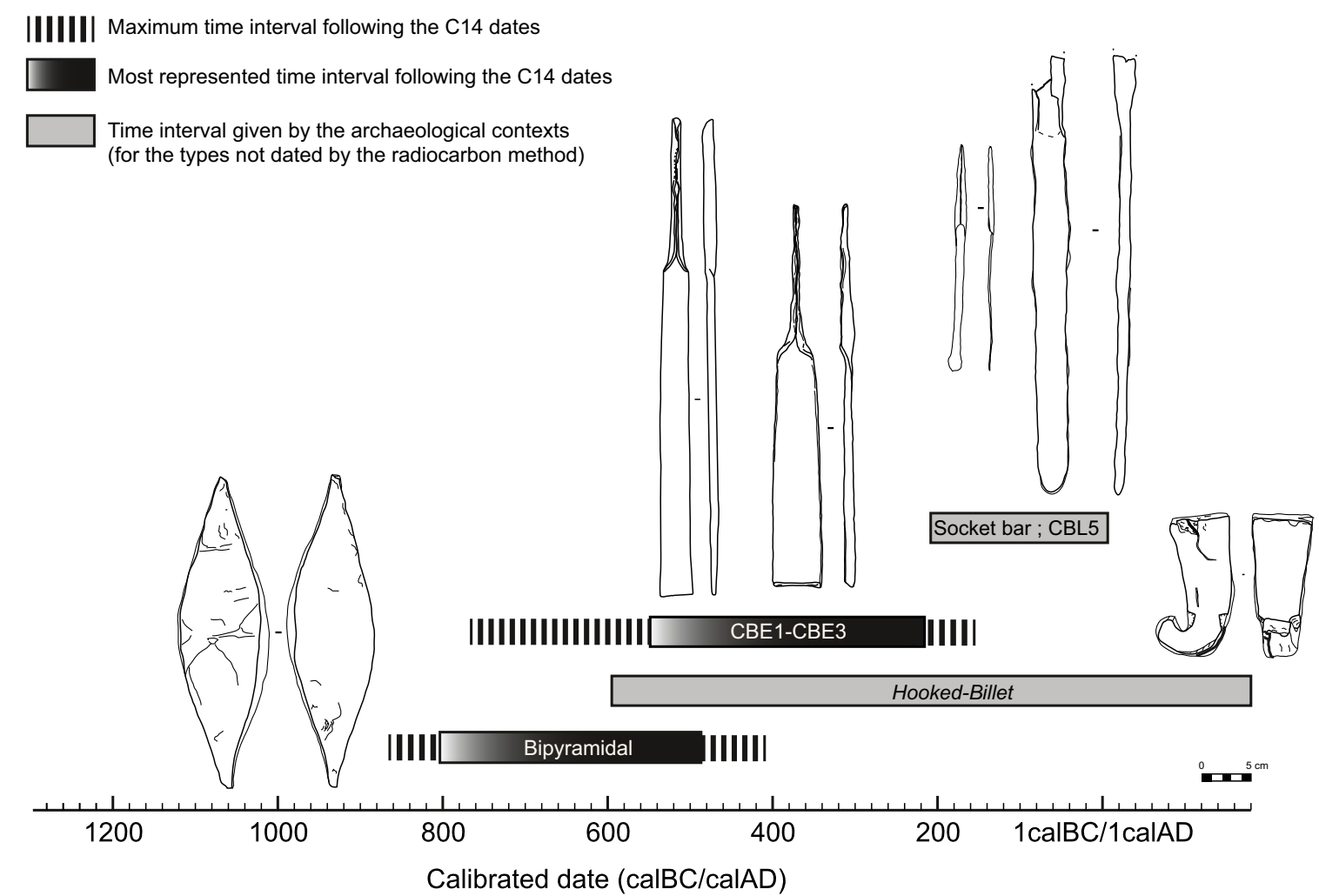

Figure 12 : ProposedtypochronologyofIronAgeferroussemi-products(CBforcurrency-bar)

A multiplicity of forms of premonetary metal deposits during the first Iron Age

Whether bipyramidal in shape or flat bars with a rolled-up extremity, all first Iron Age semi-products underwent similar manipulations. They were abandoned in series of identical objects, separate from any known sites of human occupation, and with no other associated artefacts. These characteristics are also reminiscent of the mono-specific deposits of Armorican first Iron Age bronze socket axes (Gomez de Soto 2015; Milcent 2017).

The deposition of bipyramidal bars, and a little later of currency-bars, was thus part of the more general phenomenon of the resumption of the burial of metal objects in Gaul during the Hallstatt D period (8thearly 5th c. BC). During this peri- od, the use of iron gradually replaced the use of copper-based alloys. The deposits of iron semi-products would have then constituted an extension of earlier practices concerning copper-based objects. The abandonment of these different types of metallic products could have occurred in a contem- porary manner if we consider that bronze axes may have cir- culated until the first half of the 5th century BC (ibid.).

The Armorican Peninsula has such a concentration of de- posits of socket bronze axes that the term "Armorican" is associated with these objects. Bipyramidal bars, the earliest type of iron semi-products in circulation, are also well repre- sented in this part of France. Nevertheless, it is especially the North-Alpine area, with very little abandonment of socket axes, that has the largest quantities of bipyramidal bar de- 
posits. Within the context of the emerging new ferrous mate- rial, these clear geographical differences could then testify to cultural choices related to the reorganisation of trade networks.

The clear absence of a technical use for Armorican socket axes - too thin, too rich in lead, poorly cast and then miniaturised at the end of the period - has long been emphasised to support their identification as a paleomonetary product. Pierre-Yves Milcent recently pointed out that, having lost their use value, they would have retained only a premonetary exchange value (Milcent 2017, pp. 728-729). Subjected to the same abandonment practices as these bronze axes, iron semi-products did not have a morphology evoking any role other than that of a store of value. This function is indubitable for the period under consideration. The weight of a single semi-product, whether bipyramidal (average weight around 4 to $5 \mathrm{~kg}$ ) or a currency-bar (700 g on average for the specimens studied), exceeds the total weight of the iron ob- jects found in residential sites during this period. With the exception of the vast Heuneburg complex with its 12 $\mathrm{kg}$ of iron objects, residential sites generally stored no more than $1 \mathrm{~kg}$ of iron during the Hallstatt D-La Tène A periods (Dubreucq 2013, fig. 103).

Moreover, the forms, weights and even qualities of the metal were clearly standardised for these semiproducts. As real stores of value, especially for these ancient periods, they were good candidates for fulfilling a premonetary function, not for the payment of everyday objects, but rather for more specific occasions such as the payment of penalties, blood money or bride prices (Testart ed. 2001; Milcent, 2017 pp. 729-732). The specific place accorded to these objects is ev-ident on several levels: as stores of value during a period when the consumption of iron remained limited to the elite, as markers of specialised expertise, as possible symbolic or com- memorative objects given their conservation over long periods before their ritualised deposit (as, perhaps, in Champdivers), and by potentially being recycled from aristocratic objects (as in Valempoulières).

During the period under consideration, a succession in the constitution modalities of the deposits of semiproducts is per- ceptible. Initially, they included large metal masses, taking the form of bipyramidal bars of variable quality; this variability was sometimes observed within the same deposit (Bauvais et al. 2017). Then lighter but higher quality products repre- sented by currency-bars were deposited. While the spread of metal started to concern a larger part of society, the value of these deposits no longer seemed to be represented so much by the weight of the metal sacrificed as by the quality of the product, resulting from the mastery of a specific expertise. At the end of the Iron Age, deposits occur in sanctuaries of series of iron semi-products such as socket bars, weighing about a hundred grams but of very high quality (Berranger and Fluzin 2012), reflecting a new appreciation for the tech- nical mastery of craftsmen faced with the increase in iron consumption.

\section{Conclusion}

This interdisciplinary study carried out on a set of 73 curren-cy-bars, semi-products originating from the bed of the Saône, an oxbow of the Doubs around Champdivers and a series of rocky deposits in the Salinsles-Bains region, made it possible to better characterise their manufacturing and trade conditions and to date them using the radiocarbon method.

These dates, which mainly fall within the first Iron Age (8th-early 4th c. BC) and extend to the 3rd century $\mathrm{BC}$, allow a re-evaluation of the archaeological timescale of these objects, which up to now had been exclusively attributed to the second Iron Age.

A new three-phase typochronology is proposed. The first phase, an ancient period covering the first Iron Age, was characterised by the circulation of massive bipyramidal semi-products. Then, a second phase, from the end of the first Iron Age until the 3rd century BC, witnessed the circulation of CBE1- and CBE3type currency-bars. The final phase, cover- ing the last two centuries BC, saw the circulation of lighter, higher quality semi-products in the form of socket bars and other types of currency-bars with a larger rolled-up extremity (type CBL5).

The singularity of the manufacturing techniques of these semi-products and the chemical compounds characteristic of their origins have made it possible to highlight their integra- tion in diversified and codified trade networks that probably included different intermediaries. The metal used for their 
manufacture came from multiple production centres, some of which commonly supplied the Saône, Doubs and Salins- les-Bains sectors. Iron first circulated as a raw product before being transformed in forge workshops with standardised pro- duction conditions. The multiple origins observed within a single deposit could indirectly attest to the involvement of different actors in gathering the raw iron.

The depositing of these semi-products within the chrono- cultural context of the first Iron Age would thus be part of a wider phenomenon concerning objects made of copper-based alloys or iron, taking the form of technically useless axes, bipyramidal products or flat bars with rolled-up extremities, intended for the payment of social obligations. These iron semi-products, stores of both metal and craftmanship, appear to be polymorphic objects, vectors of specialised exchanges as well as symbolic and commemorative practices.

Supplementary Information The online version contains supplementary material available at https://doi.org/10.1007/s12520-02101333-0.

Acknowledgements We thank our colleagues at the Centre Ernest Babelon (IRAMAT-UMR5060-CNRS) in Orléans for access to the ICP-MS, as well as for their assistance during the analysis. The authors acknowledge the ARTEMIS staff for sample preparation and AMS op- erating. The LMC14 is funded by five French organisations: CEA, CNRS, IRD, IRSN and the Ministry of Culture. Finally, we would like to express our sincere thanks to the various persons and institutions who provided access to the objects studied: H. Grut, P. Moscat and J.-F. Piningre (SRA Franche-Comté) for the Salins-les-Bains region and L. Bonnamour, G. Marchet-Legendre and C. Michel at the Musée Denon in Chalon-sur-Saône. We gratefully thank Sylvain Bauvais for the fruitful exchanges and discussions.

\section{References}

The authors declare no competing interests.

Allen D (1967) Iron currency bars in Britain. Proceedings of the prehis- toric soc., XXXIII, 307-335.

Bauvais S, Dillmann P, Disser A, Leroy S, Berranger M, Pagès G, Vega E (2015) Circulation of iron products in the Iron-Age of Eastern France and Southern Germany: multidisciplinary and methodologi- cal approaches towards the provenance of ancient iron. Final report of ANR-DFG programm, Laboratoire Métallurgies et Cultures- IRAMAT, Laboratoire Archéomatériaux et Prévention de l'altération, CEA Saclay

Bauvais S, Berranger M, Boukezzoula M, Leroy S, Disser A, Vega E, Aubert M, Dillmann P, Fluzin P (2017) « Guard the good deposit » : technology, provenance and dating of bipyramidal iron semi- products of the Durrenentzen deposit (Haut-Rhin, France). Archaeometry 60:290-307. https://doi.org/10.1111/arcm.12306

Berranger M. (2014) Le fer, entre matière première et moyen d'échange, en France du VIIe au Ier s. av. J.-C. Approches interdisciplinaires. Éditions universitaires de Dijon, coll. Archéologie et Patrimoine, Dijon

Berranger M, Bauvais S (2020) Changements sociétaux et évolution de l'économie du fer du Hallstatt D à La Tène D dans le nord-est de la France. Bull. de la Soc. Préhistorique Française 117-4:641-671

Berranger M, Fluzin P (2012) From raw metal to semi-product: quality and circulation of materials during the Iron Age in France. Archaeometry 54:664-684. https://doi.org/10.1111/j.1475-4754. 2011.00641.x

Berranger M, Fluzin P (2016) Technotypologie des «currency-bars » issus de la Saône: prolongements interdisciplinaires. Vitali D, Goudineau C dir, Le monde celtique avant et après la conquête romaine. Mélanges en l'honneur de Jean-Paul Guillaumet, Musée archéologique Luigi-Fantini, Bologne-Dijon, 281-292

Berranger M, Zaour N, Leroy M, Bauvais S, Cabboi L, Dunikowski C (2017) Organisation des productions sidérurgiques en Gaule (VIIe- Ier siècle av. J.-C.): de la réduction du métal à l'élaboration des demi-produits. Marion S, Deffressigne S, Kaurin J, Bataille G, Production et proto-industrialisation aux âges du Fer, Actes du 39e colloque de l'AFEAF Nancy 14-17 mai 2015, Ausonius, Mémoires 47, Bordeaux, 301-334

Blancquaert G, Adrian Y-M (2006) Les occupations multiples de la Plaine du Bosc Renault à Hautot-le-Vatois (Seine-Maritime): la zone de stockage du premier âge du Fer et les vestiges antiques funéraires et domestiques. Revue archéol.e de l'Ouest, 23, 9-44

Bronk Ramsey C (2009) Bayesian analysis of radiocarbon dates. Radiocarbon 51-1:337-360

Brun P, Chaume B, Dhennequin L, Quilliec B (2009) Le passage de l'âge du Bronze à l'âge du Fer... au fil de l'épée. De l'âge du Bronze à l'âge du Fer en France et en Europe occidentale (Xe-VIIe siècle av. J.-C.). La moyenne vallée du Rhône aux âges du Fer, Actes du XXXe 
colloque de l'AFEAF, co-organisé avec l'APRAB, Saint- Romain-en-Gal, 26-28 mai 2006, Revue archéologique de l’Est, Supplément 27, Dijon, 477-485

Cararra S, Dubreucq E, Pescher B (2013) La fabrication des fibules à timbale comme marqueur des contacts et des transferts technologiques au cours du Ha D-LT A1. Nouvelles données d'après les sites de Bourges, Lyon et Plombières-les-Dijon. Colin A, Verdin F, L'âge du Fer en Aquitaine et sur ses marges. Mobilité des hommes, diffusion des idées, circulation des biens dans l'espace européen à l'âge du Fer, actes du $35^{\mathrm{e}}$ colloque de l'AFEAF, Bordeaux, juin 2011, suppl. Aquitania 30, 595-608

César : Guerre des Gaules, éd. et trad. L.-A. Constans, revue et corrigée par A. Balland, Paris, Les Belles Lettres, coll. CUF, série latine 32,2014

Charlton MF, Blakelock E, Martinon-Torres M, Young T (2012) Investigating the production provenance of iron artifacts with multivariate methods. J Archaeol Sci 39:2280-2293

Crew P (1994) Currency bars in Great Britain, typology and function, in Mangin M dir, La sidérurgie ancienne de l'Est de la France dans son contexte européen, Archéologie et archéométrie, Actes du colloque de Besançon, 10-13 novembre 1993, Annales littéraires de l’université de Besançon, Les Belles Lettres, Paris, 175-176

Daubigney A, Barral P, Canet S, (2007) Le dépôt laténien et romain de Champdivers dans la basse vallée du Doubs (Jura). Barral P, Daubigney A, Dunning C, Kaenel G, Roulière-Lambert M-J, L'âge du Fer dans l'arc jurassien et ses marges. Dépôts, lieux sacrés et territorialité à l'âge du Fer, vol. II, Actes du XXIXe colloque de l'AFEAF, Bienne 5 au 8 mai 2005, Presses universitaires de FrancheComté, Annales Littéraires, Série Environnement, sociétés et archéologie, Besançon, 405-424

Dillmann P, L’Héritier M (2007) Slag inclusion analyses for studying ferrous alloys employed in French medieval buildings: supply of materials and diffusion of smelting processes. J Archaeol Sci 34-11:1810-1823

Dillmann P, Schwab R, Bauvais S, Brauns M, Disser A, Leroy S, Gassmann G, Fluzin P (2017) Circulation of iron products in the NorthAlpine area during the end of the first Iron Age (6th-5th c. BC): a combination of chemical and isotopic approaches. J Archaeol Sci 87:108-124

Disser A, Dillmann P, Leroy M, Merluzzo P, Leroy S (2016) The bridge of Dieulouard (Meurthe-et-Moselle, France): a fresh perspective on metal supply strategies in Carolingian economy. ArcheoSciences 40-1:149-161

Disser A, L'Héritier M, Dillmann P, Arles A (2017) Le chantier de la tour de Mutte à Metz: regards sur la production du fer en Lorraine à la fin du Moyen Âge. Fouille de données, analyses prédictives et traitement spatial des données, Jo de la Soc. française de Stat. 1582, 13-39

Dubreucq E (2013) Métal des premiers celtes, productions métalliques sur les habitats des provinces du Hallstatt centre-occidental, Éditions universitaires de Dijon, coll. Art, Archéologie et Patrimoine, Dijon

Dubreucq E, Piningre J-F (2007) Un dépôt d'armes du IIIe siècle avant J. C. à Bourguignon-les-Morey (Haute-Saône). Barral P, Daubigney A, Dunning C, Kaenel G, Roulière-Lambert M-J, L'âge du Fer dans l'arc jurassien et ses marges. Dépôts, lieux sacrés et territorialité à l'âge du Fer, vol. II, Actes du XXIXe colloque de l'AFEAF, Bienne 5 au 8 mai 2005, Presses universitaires de FrancheComté, Annales Littéraires, Série Environnement, sociétés et archéologie, Besançon, 671-679

Dumoulin J-P, Comby-Zerbino C, Delqué-Količ E, Moreau C, Caffy I, Hain S, Perron M, Thellier B, Setti V, Berthier B, Beck L (2017) Status report on sample preparation protocols developed at the LMC14 laboratory, Saclay, France: from sample collection to 14C AMS measurement. Radiocarbon 59:713-726

Dumont A (2002) Les passages à gué de la Grande Saône, approche archéologique et historique d'un espace fluvial (de Verdun sur le Doubs à Lyon), Revue archéologique de l'Est, Suppl. 17, Dijon

Feugère M (2000) Un nouveau dépôt de lingot de fer de la Tène finale: Bretteville sur Odon (Calvados), Instrumentum 11, 15.

Gauthier E, Piningre J-F (2016) Communication visuelle autour du Camp du Château à Salins-les-Bains (Jura, France): mise en évidence d'un réseau de relations visuelles à l'âge du Bronze. Mordant C, Buchsenschutz O, Jeunesse C, Vialou D dir, Signes et communica- tion dans les civilisations de la parole, Actes du 139e Congrès na- tional des sociétés historiques et scientifiques, Nîmes, 2014, Paris, Éditions du Comité des travaux historiques et scientifiques, URL : http://books.openedition.org/cths/1902

Golosetti R dir (2019) Mémoires de l'âge du Fer. Effacer ou réécrire le passé, Hermann éditeurs, coll. Histoire et Archéologie, Paris

Goguey D, Benard J dir. Berranger M, Chevigny E, Fovet E, Giosa A, Granjon L, Guillaumet J-P, Pautrat Y, Pillot L, Petit C, Popovitch L, Saligny L (2018) Structures en pierre du plateau du Châtillonnais (côte d'Or) du Hallstatt à l'Antiquité tardive. L'apport de l'archéologie forestière, Editions Mergoil, Dremil-Lafage, Archéol. et hist. romaine, 39 
Gomez de Soto J (2015) Les haches à douilles de type armoricain: une production strictement de l'âge du Fer. Critique des sources documentaires afférant à leur chronologie, Bull. de la Soc. préhistorique française 112, 117-136

Hendrickson M, Leroy S (2020) Sparks and needles: seeking catalysts of state expansions, a case study of technological interaction at Angkor, Cambodia (9th to 13th centuries CE). J Anthropol Archaeol 57:101141. https://doi.org/10.1016/j.jaa.2019.101141

Hieirli J (1901) Urgeschichte der Schweitz. Zurich, Verlag von Albert Müller

Hingley R (1990) Iron Age “currency bars”: the archaeological and social context. Archaeol J 147:91-117

Humpert J (1991) Eine römische Strasse durch den südlichen Schwarzwald. Archäologische nachrichten aus Baden 45:19-32

Jacobi G (1974) Werkzeug und gerät aus dem oppidum vom Manching. Stuttgart, Franz, Die ausgrabungen in Manching 5

Kaurin J, Seguin G (2013) La nécropole celtique du Chêne (Aube). Images de femmes du début du IIIe s. av. J.-C., Éditions universitaires de Dijon, coll. Arts, archéologie, patrimoine, Dijon

Kleeman 0 (1981) Les lingots de fer bipyramidaux courts et épais: les lingots du type Colmar. Revue archéologique de l’Est 32:109119

Lefevre C, Leroy M, Merluzzo P (2001) Lingots de fer de type "currency bars" à Chatel Saint Germain (F, Moselle). Instrumentum 13:39-40 Lejars T (2019) Des vestiges anachroniques ou hors-norme provenant de lieux de culte gaulois de la Tène moyenne: continuité des occupations et permanence rituelle ? in Golosetti dir. 2019, 205-223 Leroy S, Bauvais S, Delqué-Količ E, Hendrickson M, Josso N, Dumoulin J-P, Soutif D (2020) First experimental reconstruction of an Angkorian iron furnace (13th-14th centuries CE): archaeological and archaeometric implications. J Archaeol Sci Rep 34:102592. https://doi.org/10.1016/j.jasrep.2020.102592

Leroy S, Cohen SX, Verna C, Gratuze B, Tereygeol F, Fluzin P, Bertrand L, Dillmann P (2012) The medieval iron market in Ariège (France). Multidisciplinary analytical approach and multivariate analyses. J Archaeol Sci 39-4:1080-1093

Leroy S, L'Héritier M, Delque-Kolic E, Dumoulin J-P, Moreau C, Dillmann P (2015a) Consolidation or initial design? Radiocarbon dating of ancient iron alloys sheds light on the reinforcements of French Gothic Cathedrals. J Archaeol Sci 53:190-201

Leroy S, Hendrickson M, Vega E, Delque-Kolic E, Dillmann P (2015b) First direct dating for the construction and modification of the Baphuon Temple Mountain in Angkor, Cambodia. PLoS One 10(11):e0141052

Leroy S, Hendrickson M, Bauvais S, Vega E, Blanchet T, Disser A, Delque-Kolic E (2017) The ties that bind: archaeometallurical typology of architectural crampons as a method for reconstructing the iron economy of Angkor, Cambodia (tenth to thirteenth c.). Archaeol Anthropol Sci 10, 2137-2157 https://doi.org/10.1007/ s12520-017-0524-3 ,mis en ligne le 20/11/2017.

Milcent P-Y (2017) Valeurs d'usage et d'échange. La dimension prémonétaire des dépôts en Gaule atlantique du XIIIe au Ve s. av. J.-C, Bull. de la Soc. préhistorique française 114, 711-737

Millet E, Thiol S, Bandelli A, Toulemonde F, Van den Bossche B, Frouin M, Berranger M, Fluzin P (2011) Un site protohistorique à Pont- Sainte-Marie: langgraben, inhumations en silos et occupation domestique des âges du Bronze et du Fer. Rapport final d'opération, INRAP Grand Est Nord

Moreau C, Caffy I, Comby C, Delqué-Količ E, Dumoulin J-P, Hain S, Quiles A, Setti V, Souprayen C, Thellier B, Vincent J (2013) Research and development of the Artemis 14C AMS facility: status report. Radiocarbon 55:331-337

Müller-Karpe A, Müller-Karpe M (1977) Neue latènezeitliche Funde aus dem Heidetränk-Oppidum im Taunus. Germania 55:33-63

Nouvel P, Thivet M (2019) Des dépôts d'antiquités dans le sanctuaire des Champs des fougères à Mandeure? Golosetti dir 2019:225235

Pagès G, Dillmann P, Fluzin P, Long L (2011) A study of the Roman iron bars of Saintes-Maries-de-la-Mer (Bouches-du-Rhône, France). A proposal for a comprehensive metallographic approach. J Archaeol Sci 38:1234-1252

Périchon R (1982) Le site de Clermont-Ferrand-Aulnat, les fouilles de la Grande Borne. Collis J, Duval A, Périchon R, Le deuxième âge du fer en Auvergne et en Forez et ses relations avec les régions voisines, Sheffield, St Etienne, Université de Sheffield, Centre d'études Forreziennes, 30-43.

Pétrequin P, Weller 0, Gauthier E, Dufraisse A (2001) Salt springs ex- ploitations without pottery during Prehistory. From New Guinea to the French Jura. Pétrequin P, Beyries S ed., Ethno-archaeology and its transfers, Papers from a session held at the European 
Association of Archaeologists Fifth annual meeting in Bournemouth 1999, British Archaeological Reports International Series 983, Archaeopress, Oxford, 37-65

Piningre J-F, Ganard V (2004) Les nécropoles protohistoriques des Moidons et le site princier du Camp du Château à Salins (Jura), Comité des travaux historiques et scientifiques, Documents préhistoriquees 17, Paris

Quenez J-P (2011) Occupations protohistoriques à Villiers-sur-Seine (Seine-et-Marne), Le Défendable. Actes des journées Archéol. d'Ile de France, 2004, 2005, 2009, 2010, 2011, 2 vol

Reimer P, Austin W, Bard E, Bayliss A, Blackwell P, Bronk Ramsey C, Butzin M, Cheng H, Edwards R, Friedrich M, Grootes P, Guilderson T, Hajdas I, Heaton T, Hogg A, Hughen K, Kromer B, Manning S, Muscheler R, Palmer J, Pearson C, van der Plicht J, Reimer R, Richards D, Scott E, Southon J, Turney C, Wacker L, Adolphi F, Büntgen U, Capano M, Fahrni S, Fogtmann-Schulz A, Friedrich R, Köhler P, Kudsk S, Miyake F, Olsen J, Reinig F, Sakamoto M, Sookdeo A, Talamo S (2020) The IntCal20 Northern Hemisphere radiocarbon age calibration curve (0-55 cal kBP). Radiocarbon 62: 725-757

Testart A (2001) Aux origines de la monnaie. Errance, Paris

Schaaff U (1983) Ein schwertförmiger eisenbarren vom typ Werimont-La Tène aus Rheinhessen. Bull des musées royaux d'art et d'histoire

54:95-102

Schönberger H (1952) Die spätlatènezeit in der Wetterau. Saalburg

Jahrbuch 11:21-130

Schwab H (1989) Archéologie de la 2e correction des eaux du Jura. Vol. 1

- Les Celtes sur la Broye et la Thielle. Ed. Universitaires Fribourg

Suisse, Archéol. Fribourgeoise, 5

Vouga P (1923) La Tène, monographie de la station publié au nom de la

commission des fouilles de La Tène. Karl W. Hiersman, Leipzig 
